\title{
Soil aggregation dynamics and carbon sequestration
}

\author{
R akesh K umar ${ }^{1 *}$, K isan Singh R awat ${ }^{1}$, J itendra Singh ${ }^{1}$, A shutosh Singh ${ }^{2}$ and A shish $\mathrm{R} \mathrm{i}^{3}$ \\ ${ }^{1}$ Division of Agricultural Physics, Indian Agricultural Research Institute, New Delhi- 110012, INDIA \\ ${ }^{2}$ Bihar Agricultural University, Sabour, Bihar- 813210, INDIA \\ ${ }^{3}$ Division of Soil Science and Agricultural Chemistry, Indian Agricultural Research Institute, New Delhi- 110012, INDIA \\ *Corresponding author. E-mail: rbinnu@ gmail.com \\ Recieved: April 3, 2012; Revised received: March 22, 2013; Accepted: April 11, 2013
}

Abstract: The quantity and quality of residues determine the formation and stabilization of aggregate structure for soil organic carbon (SOC) sequestration. Plant roots and residues are the primary organic skeleton to enmesh the inorganic particles together and build macro- and microaggregates while sequestering SOC. There are three major organic binding agents of aggregation: temporary (plant roots, fungal hyphae, and bacterial cells), transient (polysaccharides), and persistent (humic compounds and polymers). Conversion of natural ecosystems into agricultural lands for intensive cultivation severely depletes SOC pools. Magnitude of SOC sequestration in the soil system depends on the residence time of SOC in aggregates. Microaggregates are bound to old organic C, whereas macroaggregates contain younger organic material. Many techniques have been used to assess the SOC distribution in aggregates. Classical methods include SOC determination in aggregate fractions by wet and dry sieving of bulk soil. Isotopic methods including the determination of ${ }^{13} \mathrm{C}$ and ${ }^{14} \mathrm{C}$ with mass spectrometry are techniques to quantify the turnover and storage of organic materials in soil aggregates. Other techniques involve the use of computed tomography, X-ray scattering, and X-ray microscopy to examine the internal porosity and interaggregate attributes of macro- and microaggregates. Current state-of-knowledge has not unravelled completely the underlying complex processes involved in the sequestration, stability, dynamics, and residence times of SOC in macro- and microaggregates. There is a need to develop a unique conceptual model of aggregate hierarchy.

Keywords: Aggregation, Carbon sequestration, Soil organic carbon

\section{INTRODUCTION}

The major attention given on research related to climate change studies is the increasing atmospheric concentration of green house gases (GHGs), especially $\mathrm{CO}_{2}$. Developing technologies to reduce the rate of increase of atmospheric $\mathrm{CO}_{2}$ is an important issue of the twenty-first century. This realisation is based on numerous research outputs given by various agencies across the globe involved in climate change studies. Global surface temperatures have increased by $0.8{ }^{\circ} \mathrm{C}$ since the late nineteenth century, and 11 out of the 12 warmest years on record have occurred since 1995 (IPCC, 2007). In addition to the sea-level rise of $15-23 \mathrm{~cm}$ during the twentieth century (IPCC, 2007), there have been notable shifts in ecosystems (Greene and Pershing, 2007) and frequency and intensity of occurrence of wild fires (Running, 2006). These and other observed adverse impacts of climate changes are reportedly caused by emission of greenhouse gases through anthropogenic activities including land-use changes, deforestation, biomass burning, draining of wetlands, soil cultivation and fossil fuel combustion. There is a strong interest in stabilizing the atmospheric abundance of $\mathrm{CO}_{2}$ and other green house gases to mitigate the risks of global warming (Kerr, 2007). There are three strategies of lowering $\mathrm{CO}_{2}$ emissions to mitigate climate change (Schrag, 2007): (i) reducing global energy use, (ii) developing low or nocarbon fuel, and (iii) sequestering $\mathrm{CO}_{2}$ from point sources or atmosphere through natural and engineering techniques.

Soil and crop management practices have a profound impact on carbon (C) sequestration, but the mechanisms of interaction between soil structure and soil organic $\mathrm{C}$ (SOC) dynamics are not well understood. Understanding how an aggregate stores and protects SOC is essential in developing proper management practices to enhance SOC sequestration. Soil structure and soil organic matter (SOM) are two of the most dynamic properties that are extremely sensitive to crop and soil management. SOM is closely related to SOC dynamics in the soil because it constitutes the largest terrestrial reservoir of SOC. Interactions between soil structure and SOM determines the magnitude of the SOC pool. The SOM is a dynamic factor responsible for soil structure development (Beare et al., 1994). Stable soil structure, in turn, stores and prevents SOM from rapid decomposition. Although often used interchangeably, SOM differs from SOC, and it 
contains about $55 \%$ SOC and $45 \%$ other essential elements. Literature is replete with information on the effects of land management and living biomass on the $\mathrm{C}$ cycle and sequestration (Lal et al., 1998). There are also numerous studies with regard to the importance of SOM to soil fertility, soil erosion, and plant growth (Gale and Cambardella, 2000). These studies have improved our understanding of the interrelationships between soil biological properties and SOC, and the implications of crop and soil management to $\mathrm{C}$ sequestration (Six et al., 1999), but information on the fundamental physical and chemical processes influencing formation and stabilization of aggregates in relation to SOC sequestration is limited. Although it is well known that soil can be a major sink of atmospheric $\mathrm{CO}_{2}$ (Lal, 2004), mechanisms of interaction between soil structure and SOC dynamics are not well understood (Sainju et al., 2003). Soil aggregation being the nucleus of all mechanisms of $\mathrm{C}$ sequestration, understanding how an aggregate stores and interacts with SOC is essential for developing management strategies toward the enhancement of $\mathrm{C}$ sequestration at regional and global scales.

Soil aggregates: Soil aggregates are the secondary particles (structural units) formed through the combination of mineral particles with organic and/or inorganic binding agents (Bronick and Lal, 2005). An aggregate consists of grouping of a number of primary particles into a secondary unit. The mechanisms of formation of these aggregates involve several factors such as vegetation, soil fauna, microorganisms, impact of cations, clay particle interactions in relation to moisture and temperature as well as organic matter and clayorganic matter interactions (Baver and Gardner, 1972).

Flocculation and aggregate for mation: In a suspension, the primary particles with high zeta potential repel each other. With the addition of flocculating agent, the zeta potential is lowered, the particles collide, mutually attract each other and settle in the form of a floccule. The floccules are stable as long as the flocculating agent is present. However, aggregate formation requires the cementation or binding together of flocculated particles so that the primary particles do not disperse in water. Hence, stable aggregate formation or granulation is flocculation plus its cementation. The binding agents causing reduction of zeta potential can be organic and inorganic. Inorganic binding agents include polyvalent cations like $\mathrm{Ca}^{2+}$ and $\mathrm{Mg}^{2+}$. They form electropositive links between electronegative soil particles which causes the individual colloidal particles to come together and form small aggregates called floccules. Calcium affects the production and decomposition of organic matter in soil. It also helps in the binding action between organic colloid and clay particles.

Organic binding agents: The nature, size, strength, and configuration of aggregates depend on the action of stabilizing agents. Organic residues have their own hierarchal system in enmeshing particles and forming aggregates (Tisdall and Oades, 1982). Microbial polysaccharides stabilize macroaggregates, whereas humic compounds stabilize microaggregates. The binding agents responsible for stabilizing and arranging the aggregates are classified as temporary, transient, and persistent agents (Tisdall and Oades, 1982). Temporary agents comprise plant roots, fungal hyphae, mycorrhizal hyphae, bacterial cells, and algae. They develop simultaneously with the growth of plant roots and build up a visible organic skeleton to enmesh the mineral particles by adsorption to form young macroaggregates. Because temporary agents comprise large substances, they are mainly associated with macroaggregates, and they are greatly affected by tillage operations. Upon partial decomposition, temporary agents release fine roots, root hairs, mucilages, and other simple organic substances. Clay particles are adsorbed by these C-rich substances and placed around the decomposing materials because clay particles are more mobile than organic substances. The young residues play a major role in forming and stabilizing the macroaggregates.

Transient agents consist mainly of polysaccharides and organic mucilages. They are derived from plant and animal tissues and exudations of plant roots, fungal hyphae, and bacteria (Tisdall and Oades, 1982). They are negatively charged and are relatively immobile as they interact with clay particles (Tisdall, 1996). Because of their reduced immobility, polysaccharides remain temporarily undecomposed while binding clay particles into macroaggregates. Persistent agents include highly decomposed organic materials such as humic compounds, polymers, and polyvalent cations but their exact chemical composition is little understood. They are associated with microaggregation and long-term SOC sequestration(Blanco-Canqui and Lal, 2005). These humic compounds of high molecular weight are relatively recalcitrant and form bonds of clay-humic complexes through chelation of carboxylic or hydroxide groups with polyvalent metals $\left(\mathrm{Ca}^{2+}, \mathrm{Al}^{3+}\right.$, and $\left.\mathrm{Fe}^{3+}\right)$. Persistent agents have a long-lasting effect on microaggregate dynamics, but their role on the long $\mathrm{C}$ residence time in microaggregates is yet to be unravelled (Gale and Combardella, 2000).

Carbon sequestration: The process of transfer and secure storage of atmospheric $\mathrm{CO}_{2}$ into other longlived $\mathrm{C}$ pools that would otherwise be emitted or remain in the atmosphere is called carbon sequestration. C sequestration may be a natural or an anthropogenically driven process. The objective of an anthropogenically driven $\mathrm{C}$ sequestration process is to balance the global $\mathrm{C}$ budget such that future economic growth is based on 
a ' $\mathrm{C}$ neutral' strategy of no net gain in atmospheric $\mathrm{C}$ pool. Such a strategy would necessitate sequestering almost all anthropogenically generated $\mathrm{CO}_{2}$ through safe, environmentally acceptable and stable techniques with low risks of leakage. Soil $\mathrm{C}$ sequestration implies enhancing the pools of SOC and SIC as secondary carbonates through land-use conversion and adoption of recommended management practices (RMPs) in agricultural, pastoral and forestry ecosystems and restoration of degraded and drastically disturbed soils. Most soils under the managed ecosystems contain a lower SOC pool than their counterparts under natural ecosystems owing to the depletion of the SOC pool in cultivated soils. In general, cultivated soils normally contain $50-75 \%$ of the original SOC pool. The depletion of the SOC pool is caused by oxidation/mineralization, leaching and erosion. How the soil organic carbon is sequestered within the aggregates is a question to be answered. It requires knowledge on the dynamics of soil aggregates and soil organic carbon.

\section{MODELS OF SOIL AGGREGATION DYNAMICSAND CARBON SEQUESTRATION}

Several theories and conceptual models have been proposed to relate soil aggregation to SOC dynamics. Most of these models proclaim that soils consist of everchanging aggregates of different sizes bound together by organic and inorganic compounds. Development of the conceptual models of aggregate organization has enhanced our understanding of aggregate dynamics for sequestering SOC, but a full understanding of the mechanisms of aggregate dynamics in relation to SOC sequestration is awaiting further development (Gale and Combardella, 2000). The classical models were mainly developed to explain the processes of soil aggregation that are important to plant growth and biological activity. Current conceptual models of soil aggregation are being directed to elucidate concerns about SOC sequestration in aggregates.

Classical models: Emerson(1959) postulated a simplified model, which indicates that organic substances bridge sand and clay crystals to form and stabilize aggregates or what he called "soil crumbs." The model states that the number and nature of the bonds determine the aggregate stability. According to this model, the amount of organic $\mathrm{C}$ stored in aggregates is directly proportional to the specific surface area of clay minerals. Greenland (1965) stated that aggregates are formed and stabilized by microbial polysaccharides derived from fresh plant residues, but the action of polysaccharides depends on soil intrinsic characteristics.

Edwards and Bremner (1967) argued that the formation of macroaggregates results from a systematic linkage of microaggregates and these are the product of bonding

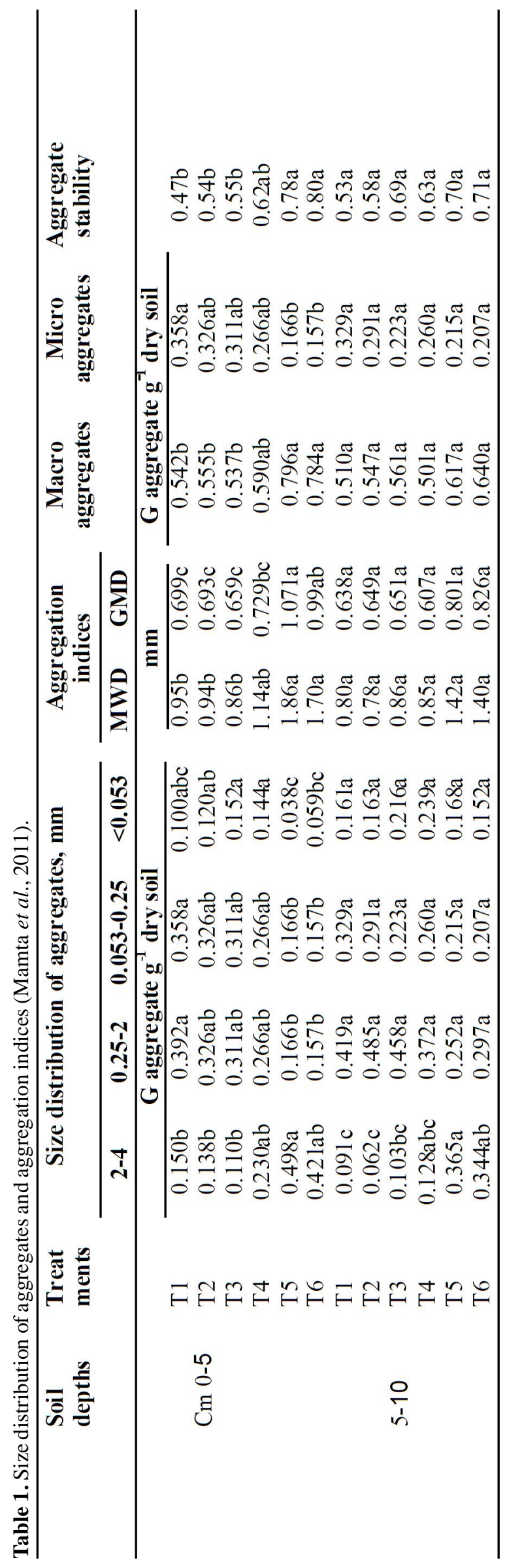


TEMPERATE and TROPICAL

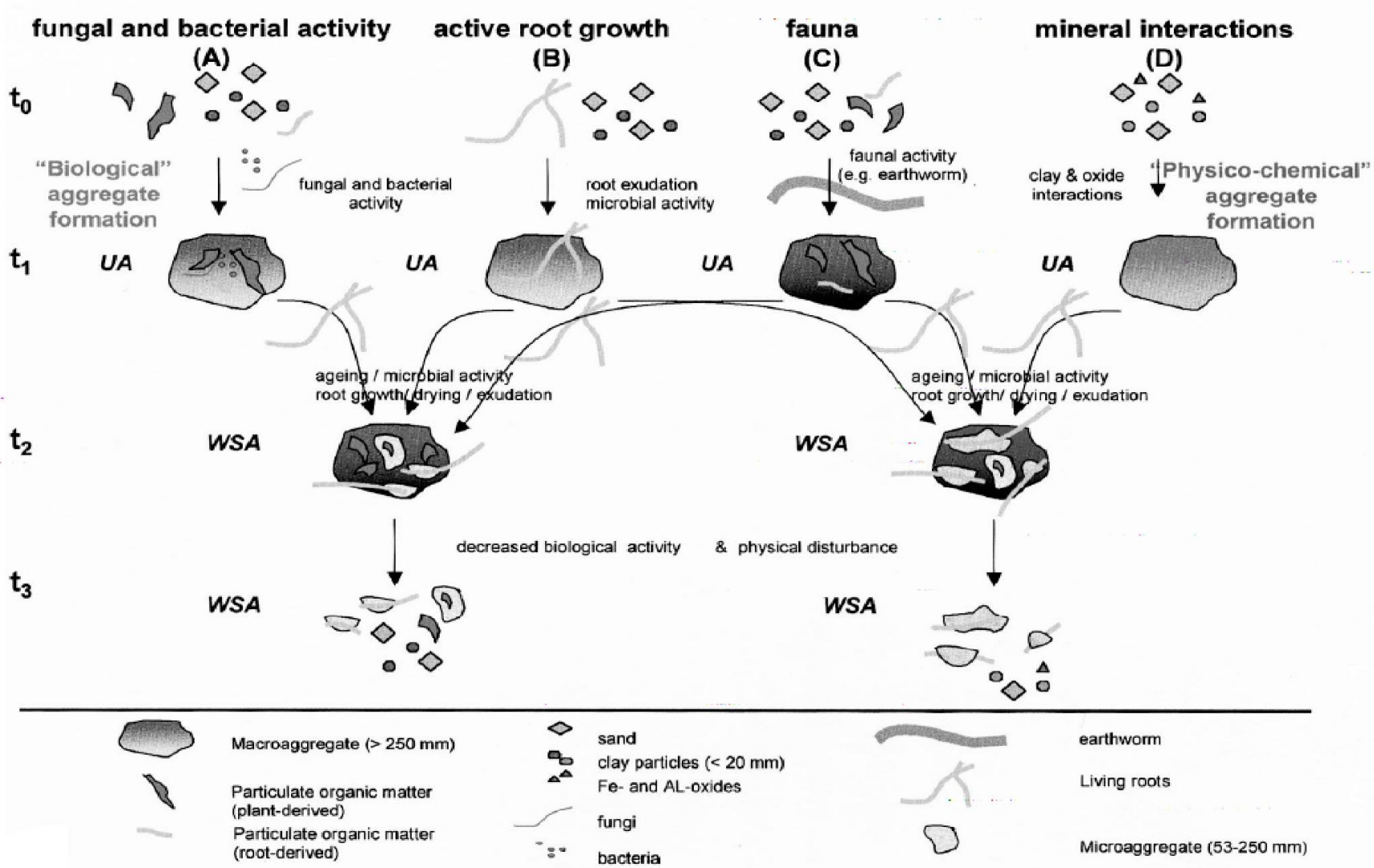

Fig. 1. Aggregate formation and degradation mechanisms in temperate and tropical soils (Six et al., 2002).

of $<2 \mu \mathrm{m}$ microstructures consisting of organo-mineral complexes. This model thus suggests that bonds within the microaggregates are much stronger than those between the microaggregates forming blocks of macroaggregates.

Tisdall and Oades (1982) proposed a pioneering conceptual model for aggregate hierarchy in which SOM is the principal binding agent of aggregate formation. He explained that binding of microaggregates is responsible for the formation of macroaggregates. Primary particles and then microaggregates are linked together to form macroaggregates. The model proposed four stages of macro and microaggregation.

Contempor ary models: Oades (1984) revised this model of aggregate hierarchy and indicated that macroaggregates $(>250 \mu \mathrm{m})$ burst into microaggregates ( 20 to $250 \mu \mathrm{m}$ ) as a prior step in forming microaggregates. According to this model, microaggregates are primarily formed within macroaggregates. Golchin et al. (1998) proposed a model similar to that of Oades (1984) where unstable and fresh macroaggregates break down in medium microaggregates $(<250 \mu \mathrm{m})$ and then into small microaggregates $(<20 \mu \mathrm{m})$ occluding fine POM in their interior. The model by Golchin and colleagues, however, stresses the importance of POM to aggregation. The POM is the active pool of SOM, which is comprised mostly of coarse and fine unstable organic detritus in various stages of decomposition and constitutes between 10-20\% of the total SOM. It differs from the passive organic pool because it is readily decomposable. Free POM from coarse residues in contact with the soil adsorbs soil particles through microbial colonization, forming clusters of macroaggregates. The POM fraction within microaggregates is protected from microbial decomposition (Golchin et al., 1998).

Another conceptual model was given by Six et al., in 2002. He gave the model of interactions between aggregation and biota activity. Aggregates are known to physically protect $C$ and $N$. Aggregates physically protect SOM by (1) forming a physical barrier between microorganisms plus microbial enzymes and their substrates, (2) controlling food web interactions, and (3) influencing microbial turnover. A closer look at the processes involved in aggregate formation and stabilization in temperate versus tropical soils illustrates the close relationship between soil biota and SOM dynamics.

In both temperate and tropical soils, there are several biological processes responsible for the formation of initial unstable "biological" macroaggregates. It is explained in Fig. 1.

Fresh plant-and root-derived residues form the nucleation 


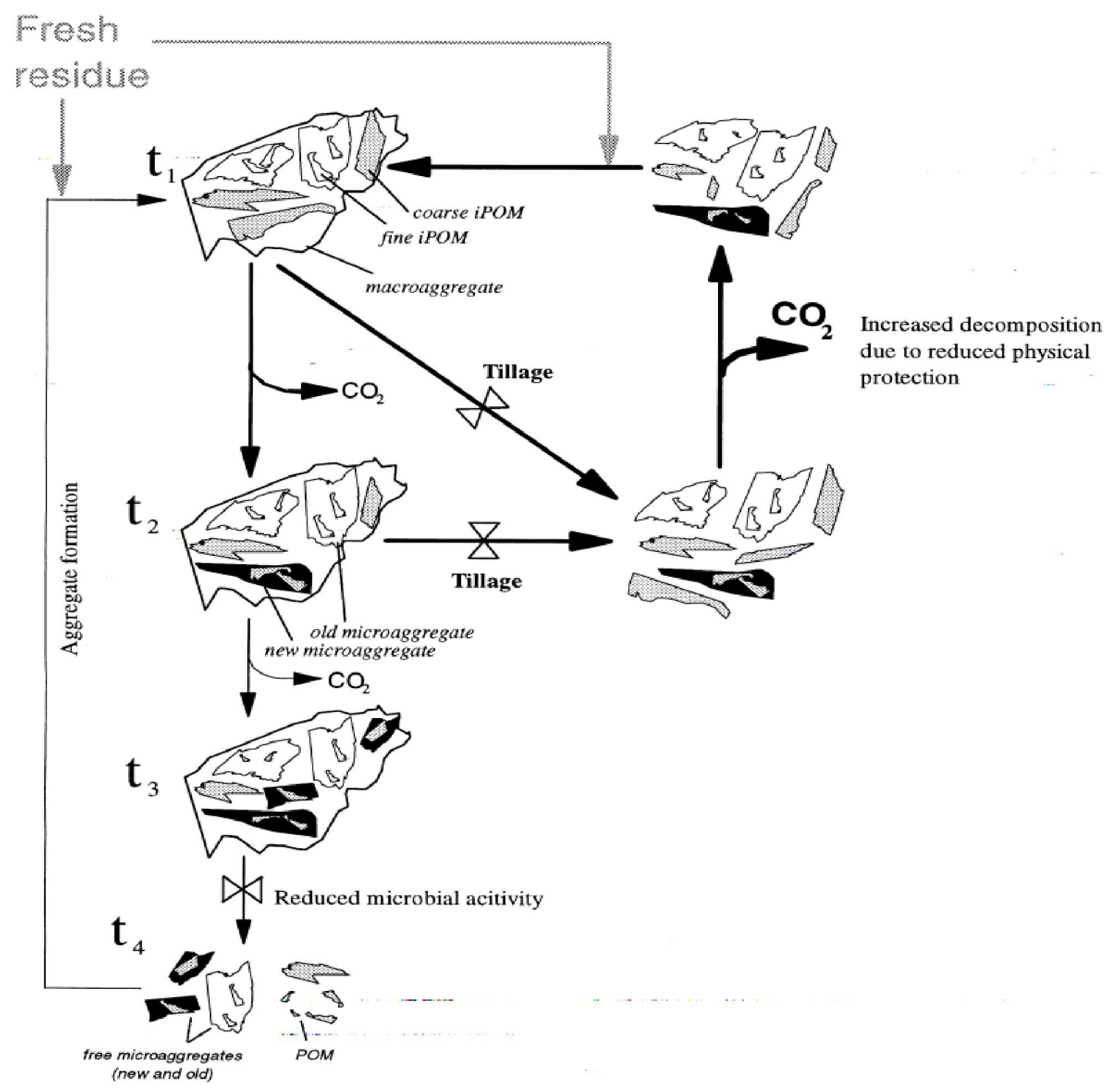

Fig. 2. The "life cycle" of a macroaggregate and the formation of microaggregates (Six et al., 2000).

sites for the growth of fungi and bacteria. Fungal hyphae initiate macroaggregate formation by enmeshing fine particles into macroaggregates. Microbial (bacterial and fungal) exudates, produced as a result of decomposition of fresh residue, form binding agents that further stabilize macroaggregates $(\mathrm{t} 1, \mathrm{~A})$.

Biological macroaggregates also form around actively growing roots in both temperate and tropical soils. Similar to fungal hyphae, roots can provide the mechanical framework for initial formation of macroaggregates by enmeshing particles and production of cementing agents (root exudates), which stimulates microbial activity ( $\mathrm{t} 0, \mathrm{~B}$ tot $1, \mathrm{~B})$.

A third common mechanism of biological macroaggregate formation in temperate and tropical soils is through the activity of soil fauna, i.e., earthworms, ants and termites. As an example, earthworms produce casts that are rich in organic matter $(\mathrm{t} 1, \mathrm{C})$. However, casts are not stable when they are freshly formed and wet. When earthworms ingest soil and particulate organic matter, large amounts of watery mucus are added to it and the soil undergoes a thorough kneading. This moulding of the soil will break bonds between soil particles, thereby reducing stability. However, this close contact between organic matter, mucus and soil particles in casts can lead to highly stable casts upon drying.

The formation of water-stable aggregates (WSA) that can resist slaking (i.e., air drying and quick submersion in water before sieving) occurs through several processes (t1 to $\mathrm{t} 2$ ): 


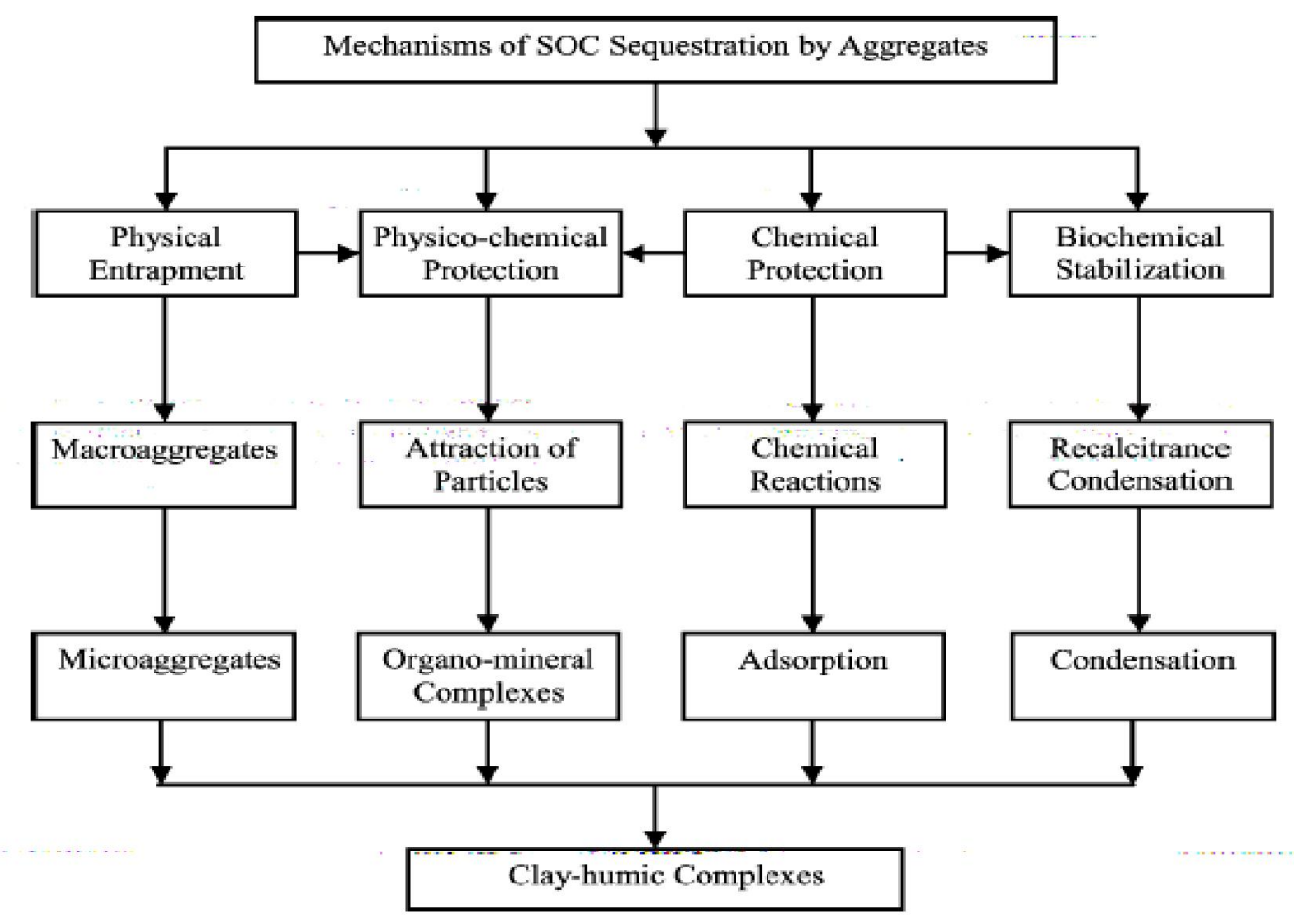

Fig. 3. Pathways of soil organic carbon (SOC) sequestration by aggregates ( $L$ al, 2004).

Under wet conditions, ageing may increase the stability of biological macroaggregates by thixotropic processes and binding through microbial activity. Microbial activity is stimulated inside the biological macroaggregates (and especially inside worm casts) because of their high organic matter content. As a result, substantial amounts of polysaccharides and other organics are deposited and serve to further stabilize the macroaggregates.

D ry-wet cycles can cause closer arrangements of primary particles, resulting in stronger bonding and increased aggregate stability.

In the presence of active root growth, biological and physicochemical macroaggregates can become even more stabilized due to biological and physical processes induced by the roots penetrating the aggregates. As mentioned before, roots can produce cementing agents (root exudates), which can strongly adsorb to inorganic materials, thereby helping to stabilize aggregates. In addition, root exudation stimulates microbial activity with subsequent production of microbial binding agents. Furthermore, roots physically influence aggregation by (i) exerting lateral pressures inducing compaction, and by (ii) continually removing water during plant transpiration. This results in localized drying of the soil and cohesion of soil particles around the roots.

During macroaggregate stabilization ( $t 1$ to $t 2$ ), the intraaggregate POM (i.e., the fresh plant material that was incorporated in the macroaggregates during "biological" aggregate formation) is further decomposed by microorganisms and fragments into finer POM. This fine POM becomes increasingly encapsulated with minerals and microbial products, forming new microaggregates $(53-250 \mu \mathrm{m})$ within the macroaggregates. With active root growth stabilizing macroaggregates, intense biological activity (induced by root exudation) may also cause further encrustation of microbial products and mineral particles, forming microaggregates around root-derived POM. It has been found that this microaggregate formation within macroaggregates is crucial for the longterm sequestration of $\mathrm{C}$ because microaggregates have a greater capacity to protect $\mathrm{C}$ against decomposition compared with macroaggregates. The final step of the aggregate turnover cycle ( $\mathrm{t} 2, ! \mathrm{t} 3)$ is when the macroaggregates break down and release microaggregates and microbially processed SOM particles. The macroaggregates break up because over time with further decomposition the labile constituents of the coarse sized SOM are consumed, microbial production of binding agents diminishes and the degree of association between SOM and the soil matrix decreases. However, microaggregates are still stable enough and not as sensitive to disruptive forces as the macroaggregates, and therefore survive.

Six et al. (2000) introduced another model for explaining the differential macroaggregate turnover induced by tillage and its influence on SOM dynamics (Fig. 2). At time $1(\mathrm{t} 1)$, macroaggregates $(250 \pm 2000 \mathrm{~mm})$ are formed around fresh residue which then becomes coarse intraaggregate particulate organic matter (iPOM). The fresh 


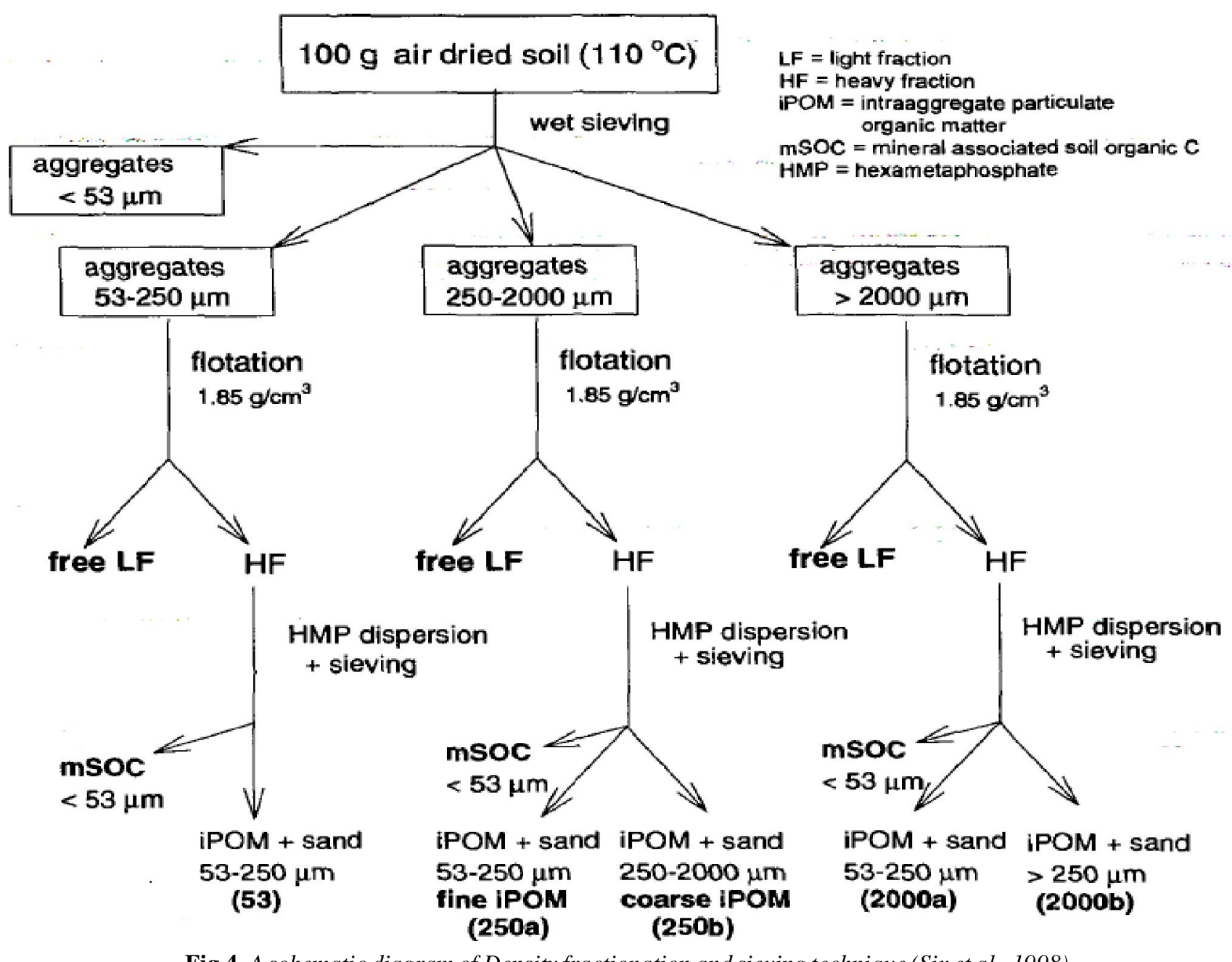

Fig.4. A schematic diagram of D ensity fractionation and sieving technique (Six et al., 1998).

residue induces the formation of macroaggregates because it is a $\mathrm{C}$ source for microbial activity and the production of microbial-derived binding agents (Six et al., 1999a). The model assumes similar rates of macroaggregate formation in NT versus CT (at t1) because the residue input is often similar in both management

SAS by wet sieving method

SAS of the different Tillage Systems $n=27$

$(1000-250 \mu \mathrm{m})$

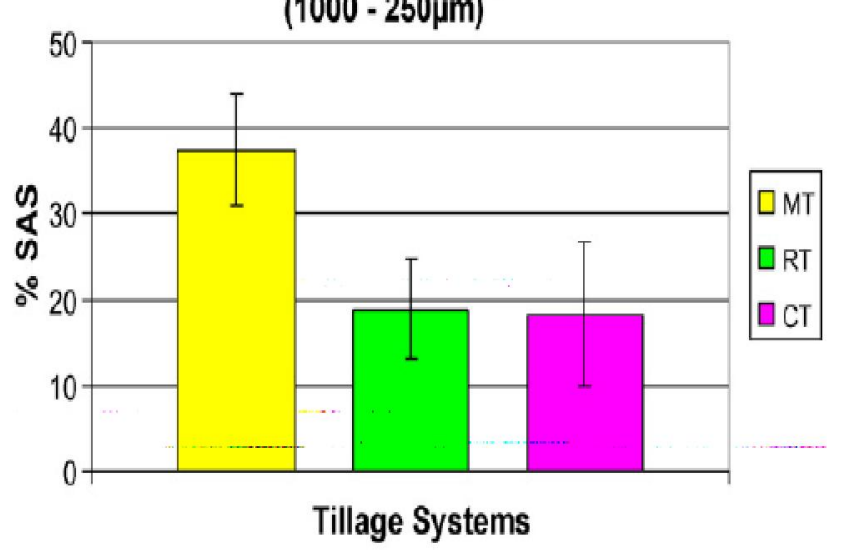

systems (Paul et al., 1997). Six et al. (1999) found that the proportion of crop-derived $\mathrm{C}$ (i.e. newer $\mathrm{C}$ ) relative to native grassland $\mathrm{C}$ (i.e. older $\mathrm{C}$ ) was similar in NT and CT macroaggregates, conforming that the rate of macroaggregate formation was similar in both management systems. Fine iPOM within a

Aggregate stability by ultrasonic dispersion method

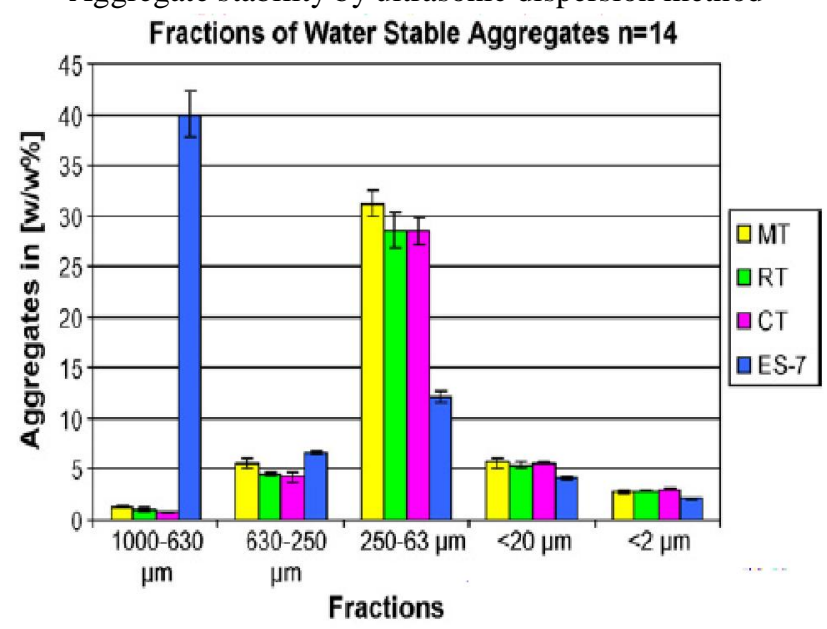

Fig. 5. Soil agg regate stability (by both Wet sieving and U SAS) (Kasper et al., 2009). 

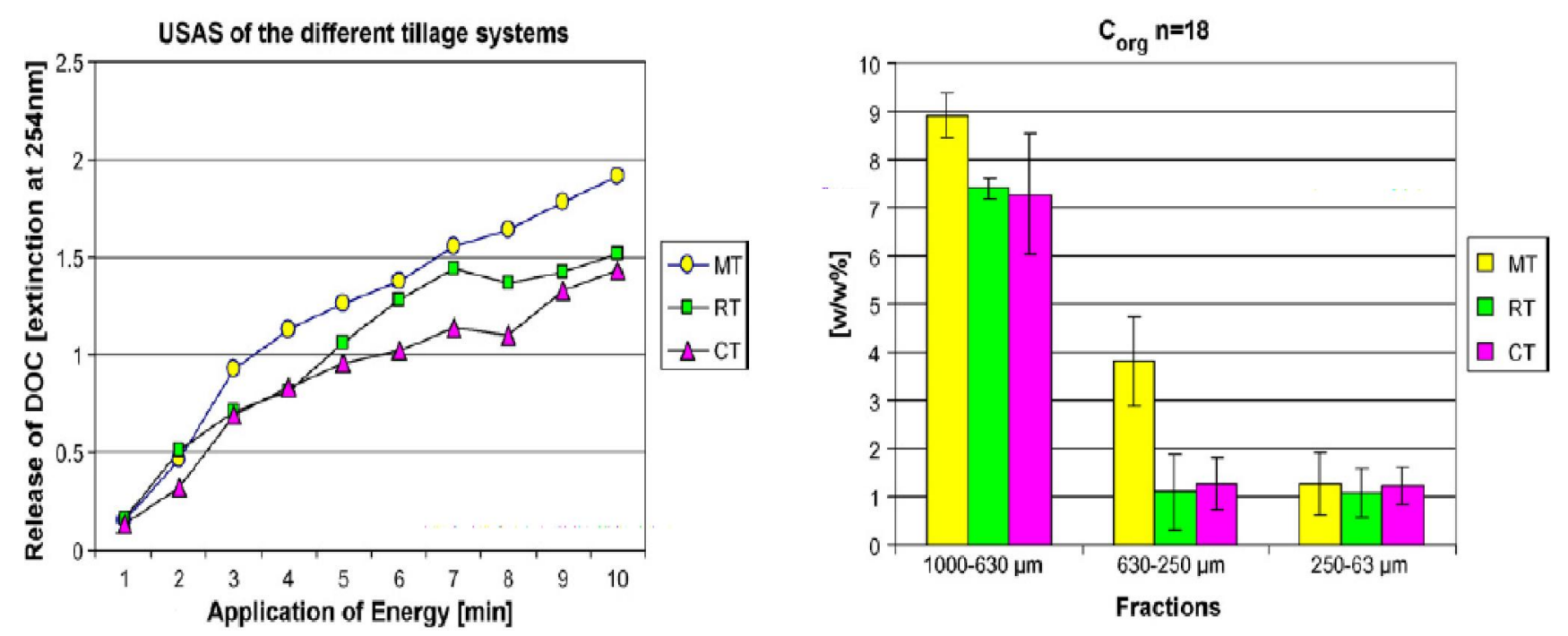

Fig. 6. Dissolved organic carbon release and organic carbon in different size fractions (Kasper et al., 2009).
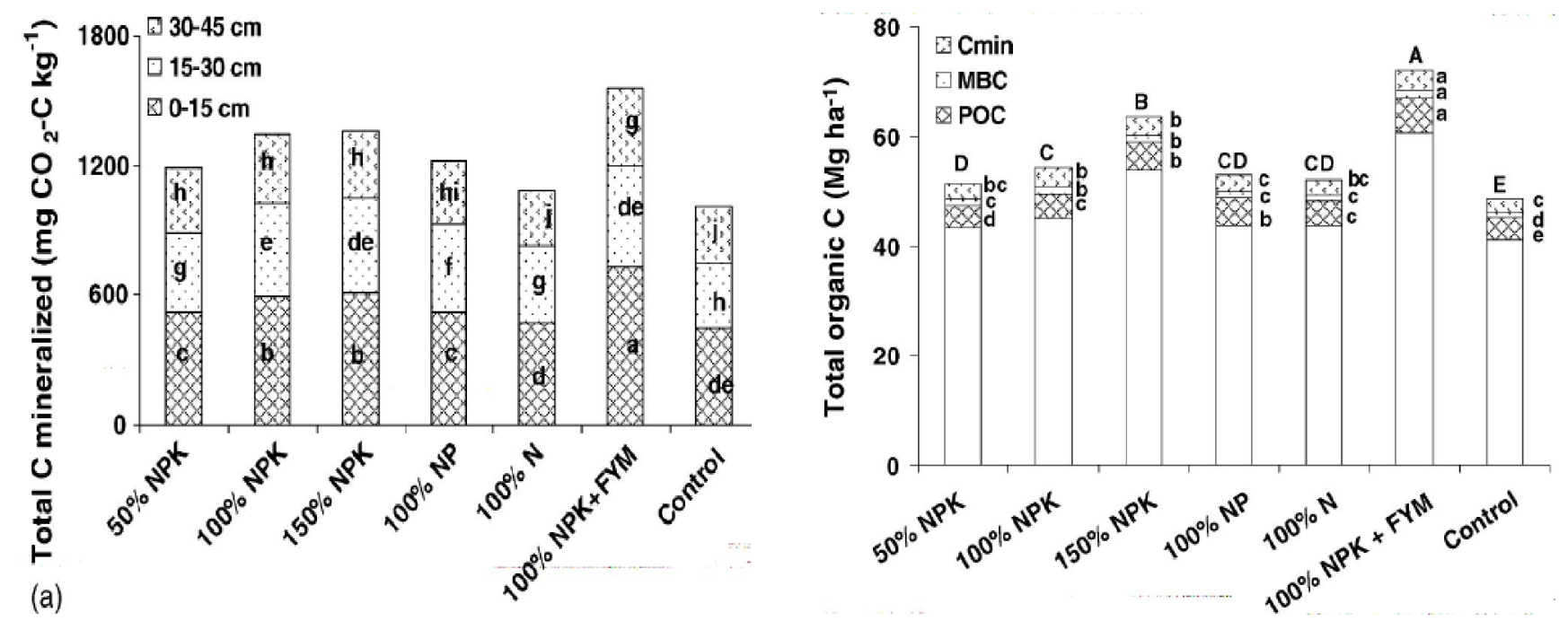

Fig. 7. Total $\mathrm{C}$ mineralized and total organic $\mathrm{C}$ under differ ent treatments (Kasper et al., 2009).

macroaggregate is derived from the decomposition and subsequent fragmentation of coarse iPOM ( $\mathrm{t} 1$ to $\mathrm{t} 2)$. This process is supported by the observations that decomposition causes decrease in POM size and that fine $\mathrm{iPOM}$ is older than coarse iPOM (Six et al., 1998). Consequently, the $\mathrm{POM}$ concentration is expected to increase with macroaggregate age. Therefore, an abundance of older macroaggregates suggests a slower macroaggregate turnover and the ratio of fine iPOM to coarse $\mathrm{iPOM}$ within macroaggregates can be used as a relative measure of the turnover of macroaggregates.

As fine $\mathrm{iPOM}$ is formed it gradually becomes encrusted with clay particles and microbial products ( $t 2$ to $t 3$ ) to form microaggregates within macroaggregates (Six et al., 1998, 1999). In isotope tracer studies, labeled C was redistributed from macroaggregates to microaggregates with time (Gale and Cambardella, 2000) suggesting that microaggregates are formed within macroaggregates (Oades, 1984). Eventually, the binding agents in macroaggregates degrade, resulting in loss of macroaggregate stability ( $\mathrm{t} 4)$ and the release of stable microaggregates, which become the building blocks for the next cycle of macroaggregate formation (Tisdall and Oades, 1982). The model suggests that the increase in macroaggregate turnover induced by tillage yields fewer new free microaggregates in CT compared to NT at $t 4$.

\section{Current knowledge}

Current state-of-knowledge based on the existing models leads to the concept that $\mathrm{C}$ sequestration is a function of the architectural system of aggregate packing. The SOC turnover decreases from macro- to microaggregates, thereby implying that there is a greater physical protection of SOC in microaggregates, which could be translated into greater SOC sequestration. The SOC in microaggregates is older than that in macroaggregates because of longer storage and less disruption. The SOC is first enmeshed in macroaggregates and then emerges as a dynamic nucleus for the formation of 

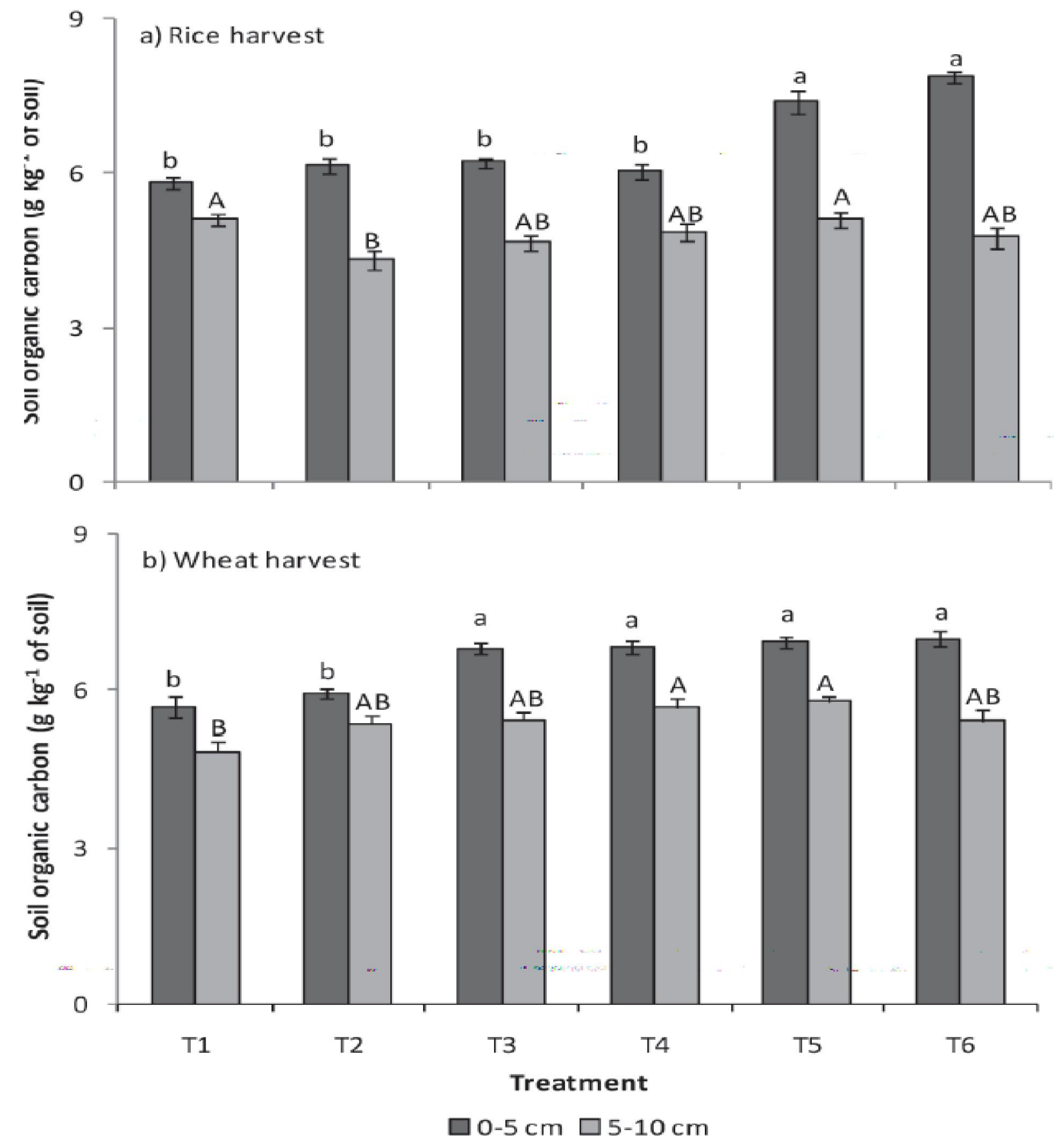

Fig. 8. Soil organic carbon contents under different treatments.

microaggregates. The SOC is essential for the formation of macroaggregates because it is a primary source of energy for the microorganisms responsible for binding soil particles (Six et al., 1999). Macroaggregates promote greater storage of SOC than microaggregates (Puget et al., 1995), but this storage is transient (Sainju et al., 2003). There is complexity associated with the interaction of microaggregates and SOC.

Available models cannot explain the aggregate hierarchy, in all soils, and are mainly valid in soils where SOM is the major binding agent (Tisdall and Oades, 1982; Oades, 1984). The SOC sequestration in the soil is governed by the degree of physical, chemical, and physicochemical stabilization of SOM inside the aggregates (Fig. 3). Physical protection refers to the entrapment of organic particles in macro- and microaggregates, whereas the chemical protection involves adsorption and recalcitrance of organic particles. Physicochemical interactive mechanisms define the maximum SOC sequestration capacity in soil (Six et al., 2002). The encrustation of SOM in the center of microaggregates is the fundamental pathway to SOC sequestration (Tisdall and Oades, 1982; Golchin et al., 1998). This process of encrustation prevents organic matter from physical and 

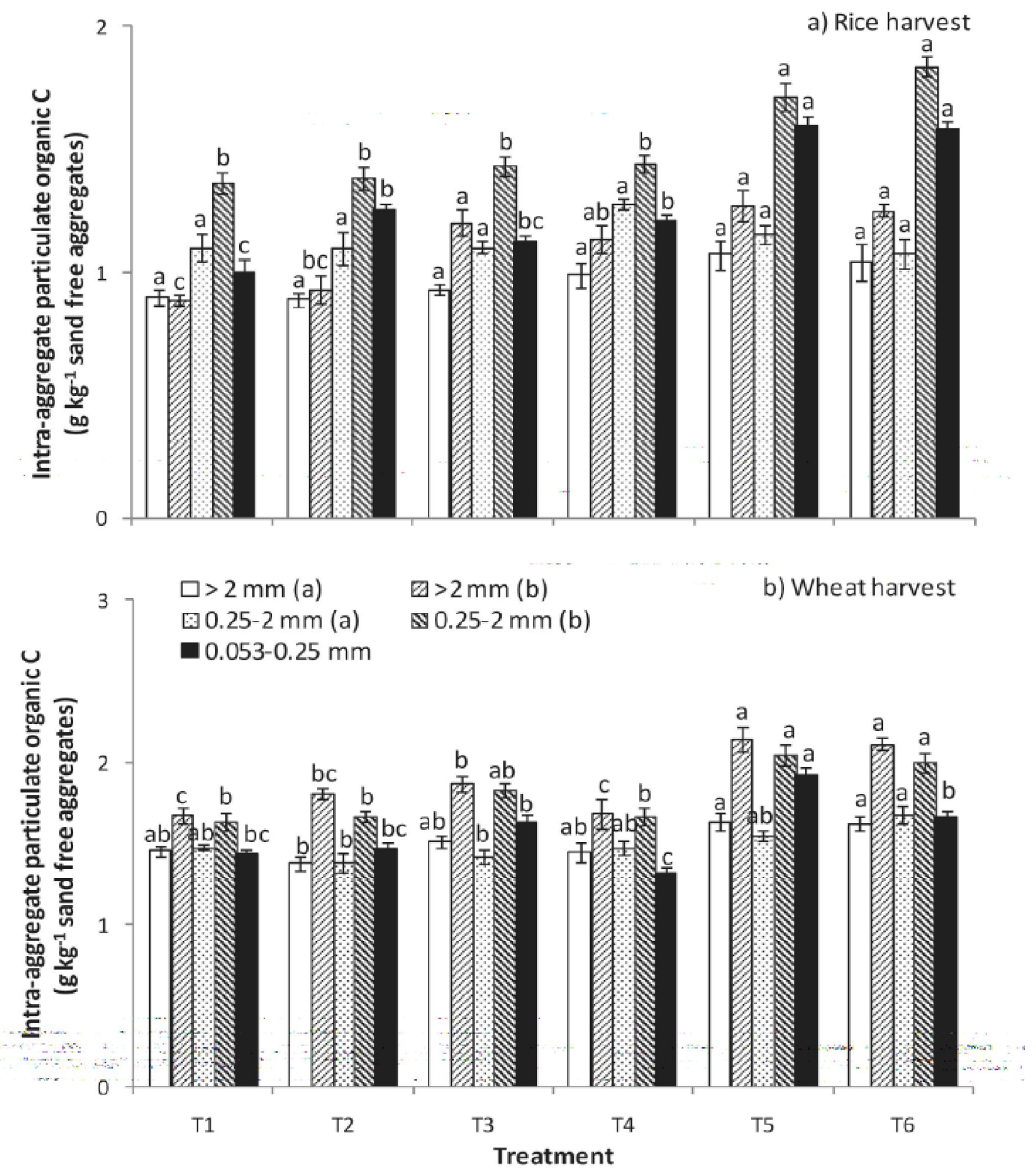

Fig. 9. Particulate organic matter (Mamta et al., 2011).

chemical decomposition by microbial processes while sequestering SOC. The protected SOC pool stabilizes the microaggregates, while the microaggregates protect the SOC from microbial processes.

Because the SOM comprises a large and heterogeneous pool of C-enriched compounds, residence time of SOC in the organic pools range from a few minutes to hundreds of years. Residence time of relatively labile organic matter can be about 7 years in both silt and clay particles, whereas residence time for stable organics can reach 400 years in silt and 1000 years in clay (Buyanovsky et al., 1994). Residence times of SOC in macro- and microaggregates may differ because of (1) differences in physiochemical attraction between mineral and organic particles and (2) location of organic binding agents within the aggregates (Emerson, 1959). The SOC residence time 


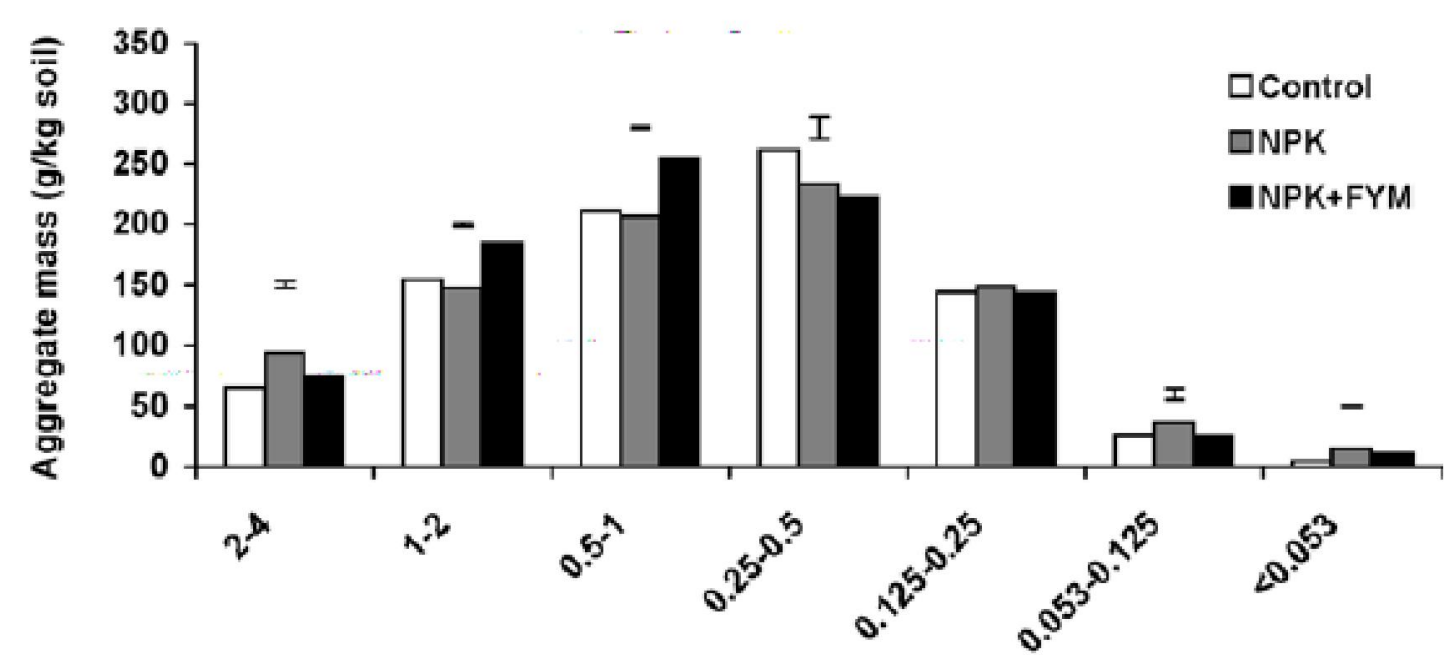

Aggregate size (mm)

Fig. 10. Aggregate size distribution (Bandyopadhyay et al., 2010).

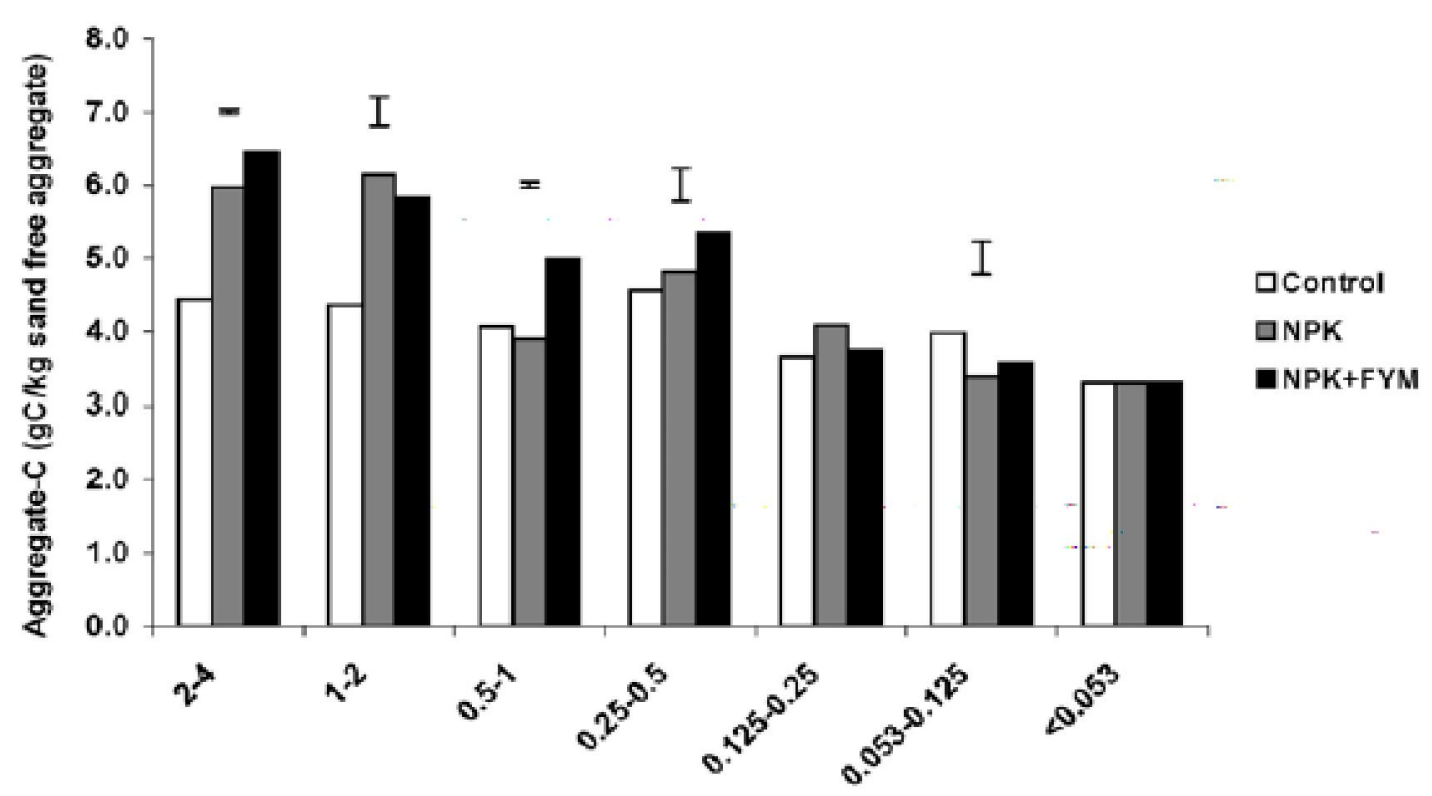

Aggregate size (mm)

Fig. 11. Distribution of SOC in different aggregates (Bandyopadhyay et al., 2010).

depends on the geo-chemical composition (Greenland, 1965), bonding agents (Tisdall and Oades, 1982), and size (Cambardella and Elliot, 1993; Six et al., 2000) of aggregates. Residence time of $\mathrm{C}$ increases with decreasing aggregate size. Losses of SOC from macroaggregates are faster and larger than those from microaggregates due to the differences in physical and chemical protection (Jastrow, 1996).

The SOC protection is proportional to the specific external surface area of clay particles, and to the monolayer interfaces between clay and sand particles. Emerson (1959) found that organic matter unavailable to microbial processes is confined between the clay crystals. The stabilizing power of clay is high, thus clay soils contain more SOC than sandy soils (Wild, 1988). Montmorillonitic clays store and protect SOC more than illitic and kaolinitic clays because montmorillonites possess greater surface area, more interlayer spaces, and higher swell and shrink potential than illites and kaolinites. Montmorillonites protect SOC by preventing the microbes from accessing the C-rich organic substrates, by controlling microbial population, and by preserving the microbial metabolites (Wild, 1988).

\section{ASSESSMENT METHODS OF SOIL ORGANIC CARBON DISTRIBUTION IN AGGREGATES}

Data on SOC distribution within aggregates are needed 


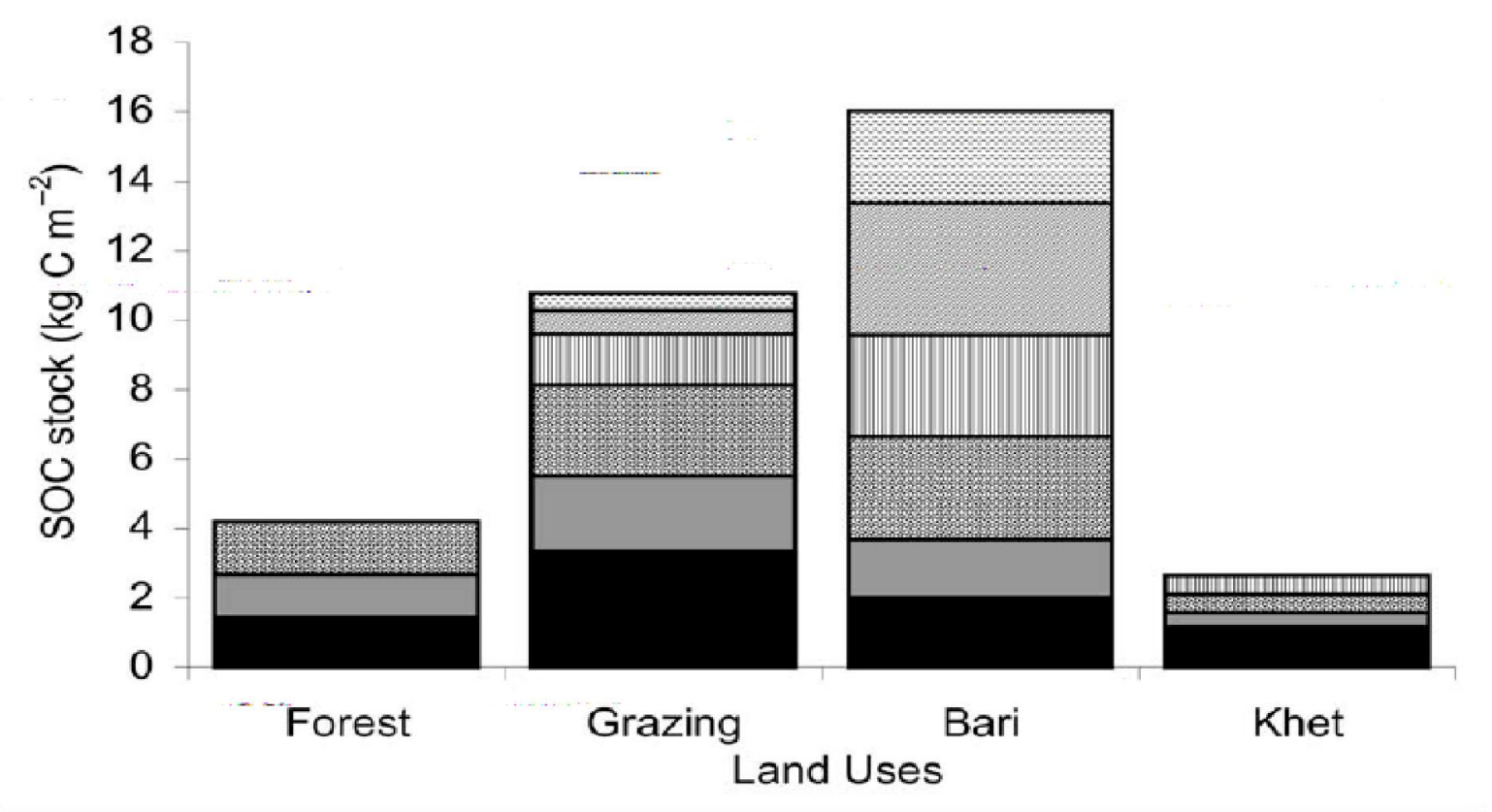

0-10 cm $\square 10-20 \mathrm{~cm} \square 20-40 \mathrm{~cm} \square 40-60 \mathrm{~cm} \square 60-80 \mathrm{~cm} \square 80-100 \mathrm{~cm}$

Fig. 12. Effect of land use on soil organic carbon stocks (Shrestha et al., 2004).

to affect a better understanding of aggregate dynamics for SOC sequestration, but measurements often require complex and expensive procedures. Whereas methods for quantifying total organic $\mathrm{C}$ in biological materials are abundant and well developed, those for assessing distribution of SOC within the aggregates are relatively few. The SOC distribution within aggregates is heterogeneous, and its assessment is a function of the method used. Therefore, attention to methods is important to draw valuable conclusions of the interrelationships between soil structure and SOC.

Classical methods: Traditional techniques of dry and wet sieving of aggregates are severely constrained in the quantification of $\mathrm{C}$ in different size fractions. Sieving and pre-treatment procedures performed prior to the determination of aggregate size distribution affect the SOC distribution in aggregates (Gale and Cambardella, 2000). Dry sieving is a preferable technique over wet sieving for maintaining a relatively intact habitat and activity of soil microorganisms (Schutter and Dick, 2002), which, however, reflects dry field conditions with no rain or irrigation.

\section{Contemporary approaches}

Density fractionation: Density fractionation is applied to isolate SOM that is not firmly associated with soil minerals (light fraction) from organo-mineral complexes (heavy fraction). The intention of density fractionation is to achieve active, intermediate and passive OM pools. Associations of SOM to mineral surfaces like e.g. phyllosilicates are most often characterized by a density greater than $1.6-2 \mathrm{~g} \mathrm{~cm}^{-3}$. Lighter fractions with a density of $1.6-2 \mathrm{~g} \mathrm{~cm}^{-3}$ mainly consist pieces of plant residues, i.e. as particulate SOM (POM), either free (fPOM) or occluded in aggregates (oPOM) (Six et al., 1998). POM has been isolated by size alone or by a combination of size and density fractionation.

Fig. 4 shows the schematic diagram used for isolation of the free LF (POM occurring between aggregates), iPOM (POM occurring within aggregates), and mineralassociated SOM (C associated with the mineral fraction) by Six et al., 1998. Aggregate separation was done by wet sieving. Here, sodium polytungstate is used to create a density gradient to separate light and heavy fractions. Carbon isotopic studies using ${ }^{13} \mathrm{C} /{ }^{12} \mathrm{C}$ ratio: Isotopic measurements of soil organic carbon have been utilized to document the effects of land use practices on ecosystems, to quantify rates and patterns of vegetation dynamics in natural ecosystems, and to refine our understanding of vegetation-climate interactions (Boutton, 1996). The natural stable carbon isotope ratio $(13 \mathrm{C} / 12 \mathrm{C})$ of soil organic carbon possesses information regarding the relative proportion of plant species with the $\mathrm{C} 3$ (low 13C/12C) and C4 (high 13C/12C) pathways of photosynthesis in past plant communities, and their relative contribution to net primary productivity (NPP) through time (Boutton, 1996). Organic matter at any depth should closely reflect the relative contribution of organic matter from $\mathrm{C} 3$ and $\mathrm{C} 4$ plants. The surface horizons of all soils reflect the $\mathrm{C} 3$ to $\mathrm{C} 4$ ratios of the current vegetation (Kelly et al., 1991). The carbon isotope composition of pedogenic carbonate is also controlled by the plant species present in the ecosystem over the time of 
Table 2. Physical properties of soil under different treatments (Bandypadhyay et al., 2010).

\begin{tabular}{lccccc}
\hline Treatment & $\begin{array}{c}\text { Water stable } \\
\text { aggregates } \\
(\%)\end{array}$ & $\begin{array}{c}\text { M ean weight } \\
\text { diameter } \\
(\mathrm{mm})\end{array}$ & $\begin{array}{c}\text { Bulk density } \\
\left(\mathrm{M} \mathrm{gm}^{-3}\right)\end{array}$ & $\begin{array}{c}\text { Hydraulic } \\
\text { conductivity } \\
\left(\mathrm{ms}^{-1}\right)\end{array}$ & $\begin{array}{c}\text { Soil organic } \\
\text { carbon }\left(\mathrm{gkg}^{-1}\right)\end{array}$ \\
\hline Control & 69.28 & 0.68 & 1.5 & $1.65 \times 10^{-4}$ & 4.2 \\
NPK & 68.06 & 0.74 & 1.44 & $2.66 \times 10^{-4}$ & 4.7 \\
NPK+FYM & 73.88 & 0.77 & 1.36 & $3.23 \times 10^{-4}$ & 6.1 \\
LSD & $\mathrm{NS}$ & 0.05 & 0.07 & $1.14 \times 10^{-4}$ & 0.7 \\
\hline
\end{tabular}

Table 3. Effect of land use changes on SOC stock (Shrestha et al., 2004).

\begin{tabular}{lcccc}
\hline L and use Change & Change in area (ha) & \multicolumn{3}{c}{ Change in SOC stock (0-40cm) } \\
\cline { 3 - 5 } & & $\begin{array}{c}\text { Per unit area } \\
\left(\mathrm{kg} \mathrm{C} \mathrm{m}^{-2}\right)^{\mathrm{b}}\end{array}$ & $\begin{array}{c}\text { W ater shed level } \\
(\mathrm{TC})^{\mathrm{c}}\end{array}$ & \% change \\
\hline Forest- Bari & 26.9 & 2.6 & 699.4 & 63.4 \\
Forest- Khet & 67 & -2 & -1340 & -48.8 \\
Forest-Grazing & 8.6 & 4.1 & 352.6 & 100.0 \\
Bari-Forest & 128 & -2.6 & -3328 & -38.8 \\
Bari-Khet & 19.4 & -4.6 & -892.4 & -68.7 \\
Bari-Grazing & 25.7 & 1.5 & 385.5 & 22.4 \\
Khet-Forest & 63 & 2 & 1260 & 95.2 \\
Khet-Bari & 4.3 & 4.6 & 211.6 & 219.0 \\
Khet-Grazing & 7.7 & 6.1 & 469.7 & 290.5 \\
Grazing- Forest & 118 & -4.1 & -4838 & -50.0 \\
Grazing-Bari & 4.3 & -1.5 & -64.5 & -18.3 \\
Grazing-Khet & 26.6 & -6.1 & -1622.6 & -74.4 \\
\hline & \multicolumn{4}{c}{ Total } \\
\hline
\end{tabular}

carbonate formation (Mermut et al. 2000). Plants with C3 pathways (most temperate region terrestrial plants) have ä13C values in the range of -21 to $-32 \%$ with a mean value of $-27 \%$, whereas $\mathrm{C} 4$ plants (many arid plants, salt marsh species, and some tropical grasses) have relatively high ä13C values ( -9 to $-17 \%$ o), with a mean of about 13\%o. Plants with the Crassulacean acid metabolism pathway are intermediate with ä13C values between -9 and $-19 \%$ with a mean value of $-17 \%$ (Boutton, 1996). Isotope ratio is expressed as following (Six et al., 1998)

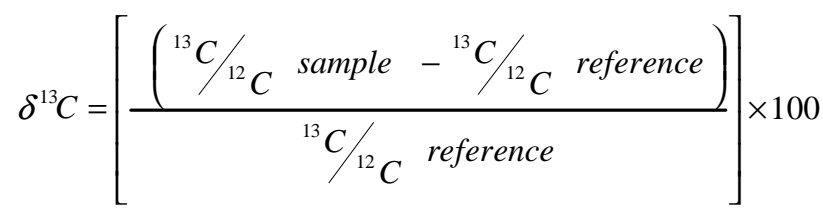

${ }^{14} \mathrm{C}$ dating method: The basis for this approach is that complex interactions of cosmic rays housed in the atmosphere generates natural radiocarbon $\left({ }^{14} \mathrm{C}\right)$ and integrates with the $\mathrm{CO}_{2}$ molecules. Plants have the ability to absorb ${ }^{14} \mathrm{C}$ from the atmosphere through photosynthesis and store it until senesce. Thus, the ${ }^{14} \mathrm{C}$ concentration in soil is correlated with that in living plants. The ${ }^{14} \mathrm{C}$ concentration decreases rapidly with vegetation loss (Adu and Oades, 1978).

Ultrasonic dispersion method: The USAS method disrupts aggregates into smaller aggregates and particles under defined energy and time conditions, without adding a chemical dispersion agent to the suspension. It is based on the fact that wetting soil is equivalent to a release of kinetic energy which can be equally achieved with ultrasonic power. Unstable aggregates are immediately disrupted and completely destroyed, and only water stable micro-aggregates and particles remain. Under natural conditions, this destruction leads to siltation. However, ultrasonic dispersion can determine not only aggregate stability, but also provides information about the chemical composition of different aggregate fractions (Mentler et al., 2004).

$X-r$ ay computed tomography: Examination of fractal dimension of soil macro- and microaggregates using Xray computed tomography $(\mathrm{CT})$ is another approach for studying aggregate dynamics in relation to SOC distribution. The computer imaging can characterize the macropore networks from a 3-dimensional perspective in aggregates (Perret et al., 2003). This approach permits the internal visualization of attributes of soil aggregates to store SOC, and can further our understanding of the mechanisms of formation and connectivity of soil pores in aggregates and structural configuration of the macroand microaggregates. The X-ray computed tomography has been extensively used to examine soil structural attributes (Crawford et al., 1995) but seldom to address 
SOC distribution in aggregates.

Case studies: This section contains some case studies related to soil aggregation dynamics and carbon sequestration affected by different tillage practices, land use practices, irrigation, nutrient management etc.

Kasper et al. (2009) studied the influence of soil tillage systems on aggregate stability and the distribution of $\mathrm{C}$ and $\mathrm{N}$ in different aggregate fractions. This study assessed the impact of different tillage systems on soil aggregates by measuring the aggregate stability, the organic carbon (Corg) and the total nitrogen (Ntot) contents within different aggregate fractions, and the release of dissolved organic carbon (DOC). Soil samples were collected from the top 0 to $10 \mathrm{~cm}$ of a long-term tillage experiment at Fuchsenbigl (Marchfeld, Austria) where conventional tillage (CT), reduced tillage (RT), and minimum tillage (MT) treatments were applied to a Chernozem fine sandy loam. The stable aggregates (1000$2000 \mathrm{~mm}$ ) were subject to dispersion by the soil aggregate stability (SAS or wet sieving) method after Kemper and Rosenau (1986), and the ultrasonic method of Mayer et al. (2002). Chemical analysis of the soil was obtained for the aggregate fractions $630-1000,250-630$ and $63-250 \mathrm{~mm}$ gathered from the ultrasonic method. The results obtained are given Fig. 5.

The aggregate stability was generally low in CT $(18.22 \%)$ and RT (18.89\%) whereas MT plots contained the largest amount of stable aggregates $>250 \mathrm{~mm}(37.57 \%)$ and reached twice the values of CT and RT (Fig. 5). A second series of measurements was undertaken in order to focus on the larger aggregate fractions of the tilled samples, by exposing them to $2 \mathrm{~min}$ of sonification and wet sieving. This resulted in a more precise measurement of aggregate stability within macroaggregates (>250 mm) (Fig. 4). Comparing these results to the previous graph, a better distinction between the tillage systems resulted since the values of the fractions $(630-250$ and $250-63 \mathrm{~mm}) \mathrm{did}$ change slightly.

The first figure shows the release from aggregates versus sonification energy applied (Fig. 6). The curves illustrate the difference between the three tillage methods. Consistently the highest release of easily soluble organic substances was recorded in MT followed by RT whereas least DOC release was recorded under CT. The C-org content in the stable aggregates reveals (a) higher content in the largest aggregates (1000-630 mm), and (b) in the 630-250 mm fraction, a significant enrichment in the MT samples. In MT, Corg is higher than in RT and CT, which supports the measured aggregate stability. There were no significant differences between the tillage systems in the micro-aggregate $(250-63 \mathrm{~mm})$ fraction. Connecting these results with the DOC measurements reveals that MT has not only the highest Corg, but also the most water soluble compounds. RT and CT have a similar content of Corg but in RT it is better soluble.

From these results we can conclude that tillage in general inhibits the development of larger stable aggregates, as the soil properties which support greater stability are generally degraded relative to uncultivated soil. This research supports the conclusion of other studies that intensive tillage systems reduce aggregate stability, and the amounts of organic carbon and nitrogen which contribute to soil quality and the long-term sustainability of agriculture. Alternative cultivation methods like minimum tillage (MT) could be a useful method to sequester more $\mathrm{C}$, which is currently a major issue.

Rudrappa et al. in 2006 carried out an investigation to study the influence of long-term applications of fertilizers and manures on different organic $\mathrm{C}$ fractions in the IARI field under intensive sequence of cropping with maize wheat-cowpea. The treatments included T1 (50\% NPK, 130:35.2:41.5 kg ha-1), T2 (100\% optimum NPK, 260:70.4:83.0 $\left.\mathrm{kg} \mathrm{ha}^{-1}\right), \mathrm{T} 3(150 \%$ NPK, 390:105.6:124.5 kg ha $\left.^{-1}\right)$, T4 (100\% NP), T5 (100\% N), T6 (100\% NPK + manure), T7 (control - no NPK or manure). The results are presented in Fig. 7.

The total amount of $C$ mineralized over 84 days at $0-15 \mathrm{~cm}$ was greater in $100 \%$ NPK + FYM followed by 150 and $100 \%$ NPK (Fig.7). While at 15-30 cm, 100\% NPK + FYM, $150 \%$ NPK and $100 \%$ NP showed similar C mineralization pattern but these were significantly higher over rest of the treatments. There was a significant increase in $\mathrm{C}$ mineralization in 100 and $150 \%$ NPK over $50 \%$ NPK treatment. The balanced application of NPK (100\% NPK) significantly increased $\mathrm{C}$ mineralization over unbalanced (100\% N and $100 \%$ NP) fertilization. Greatest accumulation of total organic C was observed with $100 \%$ NPK + FYM treatment while control plot showed the lowest value. Irrespective of depths, the balanced application of NPK (100\% NPK) showed higher accumulation of soil organic C over imbalanced use of fertilizers ( $100 \% \mathrm{~N}$ or $100 \% \mathrm{NP}$ ). The amount of sequestered organic $\mathrm{C}$ was highest in $100 \%$ NPK + FYM (731 kg ha-1 year $\left.^{-1}\right)$ followed by $150 \%$ NPK $\left(462 \mathrm{~kg} \mathrm{ha}^{-1} \mathrm{year}^{-1}\right)$ and $100 \%$ NPK $\left(169 \mathrm{~kg} \mathrm{ha}^{-1}\right.$ year $\left.^{-1}\right)$. The other treatments namely $50 \% \mathrm{NPK}, 100 \% \mathrm{~N}$ and $100 \% \mathrm{NP}$ sequestered 87, 106 and $134 \mathrm{~kg} \mathrm{C}^{-1}$ year $^{-1}$, respectively. Thus from these results, we can conclude that use of $100 \%$ NPK with farmyard manure was the most efficient management system in accumulating as well as sequestering organic $\mathrm{C}\left(72.1 \mathrm{MgC} \mathrm{ha}^{-1}\right.$ and $731 \mathrm{~kg} \mathrm{Cha}$ ${ }^{1}$ year $\left.{ }^{-1}\right)$ in $0-45 \mathrm{~cm}$ soil profile in a long-term fertilized soil. Balanced fertilization for high intensity cropping system with NPK fertilizers was found to be more effective in enhancing $\mathrm{C}$ in soil, over unbalanced fertilization.

Mamta et al. in 2011 studied the effects of various combinations of conventional and zero-tillage (ZT) and raised-bed systems on soil aggregation and associated organic $\mathrm{C}$ fractions in the $0-5-\mathrm{cm}$ and $5-10-\mathrm{cm}$ depth in a 
rice-wheat (Orysa sativa L.-Triticum aestivum L.) rotation. Six treatments (T1 to T6) involving three tillage methods (puddling and ZT planting on flat-beds and on raised-beds) and two rice establishment methods (direct drill seeding, DSR, and transplanting, TPR) were evaluated in a rice-wheat rotation. The results are given in Table 2.

Irrespective of treatments and depths, the fraction of soil macroaggregates was greater than microaggregates in both rice and wheat crops. In all cases, large macroaggregates contributed to 54 to $63 \%$ of total macroaggregates, indicating reduced turnover of aggregates under ZT systems (Six et al., 2000), possibly due to less disturbance of top layers (Table 1). Significantly higher values of MWD, GMD, and 20 to $30 \%$ improvement in aggregate stability (significant only at rice harvest) indicated better aggregation under ZT systems (T5 and T6). The relative aggregate-size fractions and the aggregation indices demonstrated that ZT promoted macroaggregation, while conventional-tillage, due to more mechanical disturbances, had less aggregation.

\section{SOIL ORGANIC CARBON}

The difference was significant in the $0-5$-cm layer. In this layer, ZT had significantly higher SOC of 7.37 and $7.86 \mathrm{~g}$ $\mathrm{kg}^{\prime \prime}{ }^{1}$ in T5 and T6, respectively than those of 5.81 and $6.14 \mathrm{~g} \mathrm{~kg}^{\prime \prime}$ in conventional tillage treatments $\mathrm{T} 1$ and $\mathrm{T} 2$, respectively (Fig.8). This indicated a greater potential for $\mathrm{C}$ accumulation with ZT likely to be associated with factors such as (a) a reduction in soil disturbance, (b) undisturbed left-over stubbles on the surface, and their slow decomposition leading to cooler soil temperature, and (c) increased soil water retention.

The mean weight diameter (MWD) increased by 62 and $76 \%$ in raised-bed and ZT systems, respectively, while in conventional tillage, the increase was only $3 \%$ compared with values at the start of an experiment.

Tillage induced changes in the intraaggregate POM-C content was distinguishable at $0-5 \mathrm{~cm}$ depth only. On average, the iPOM C content in soil was higher at wheat than at rice harvest, and accumulated in greater portion as fine $(0.053-0.25 \mathrm{~mm})$ than the coarse $(0.25-2 \mathrm{~mm})$ fraction (Fig.9). A significantly higher particulate- $\mathrm{C}$ fraction was recorded in the zero-till systems (T5 and T6), and was associated more with the fine fractions (20-30\% higher than under conventional-tillage $\mathrm{T} 1$ and $\mathrm{T} 2$ ). The accumulation of $\mathrm{C}$ in soil was related to soil aggregation and the distribution of $\mathrm{C}$ in aggregates. By significantly improving soil aggregation and associated $\mathrm{C}$ content, the potential of ZT systems in a rice-wheat rotation for enhancing $\mathrm{C}$ storage was noted. The $\mathrm{iPOM}-\mathrm{C}$ in various size classes of aggregates was perceptively influenced by tillage and was significantly higher in the zero-tillage system. Slow turnover of aggregates under the zero-tillage system resulted in fine iPOM-C sequestered within aggregates, thereby increasing the potential of $\mathrm{C}$ sequestration in the long run.

Bandyopadhyay et al., 2010 studied the effect of sole application of inorganic fertilizers (NPK) (N:P:K:: 30:26:25 $\mathrm{kg} \mathrm{ha}^{-1}$ ) and combined application of farmyard manure (FYM) @ $4 \mathrm{Mg} \mathrm{ha}^{-1}$ and inorganic fertilizers (NPK + FYM) vis-a-vis non-application of fertilizers and manures (control) on changes in soil physical properties and plant growth characteristics of soybean at the Indian Institute of Soil Science, Bhopal during the year 2001-2004. The nutrient management practices consisted of $\mathrm{T} 1$ : no fertilizer or manure (control), T2: recommended dose of fertilizer $\left(\mathrm{N}: \mathrm{P}: \mathrm{K}=30: 26: 25 \mathrm{~kg} \mathrm{ha}^{-1}\right)(\mathrm{NPK})$ and $\mathrm{T} 3$ : recommended dose of fertilizer plus farmyard manure (FYM) @ $4 \mathrm{Mg} \mathrm{ha}^{-1}$ (NPK + FYM). The results are given in Table 2.

It was observed that integrated use of NPK and FYM significantly improved the soil organic carbon content by 29.8 and $45.2 \%$ compared to NPK and control treatment, respectively (Table 2). Addition of organic matter through FYM and higher crop growth and biomass addition due to leaf shedding and root biomass addition under NPK + FYM might have contributed to higher soil organic carbon content. There was improvement in the percentage of water stable aggregates $(>250 \mu \mathrm{m})$ due to integrated use of recommended dose of NPK and farmyard manure (FYM). However, the effect was not statistically significant. The mean weight diameter of the water stable aggregates also increased significantly due to integrated use of NPK and FYM. The mean weight diameter and the water stable aggregate percentage were significantly positively correlated with the soil organic carbon content. The bulk density under integrated use of NPK and FYM was 5.6\% lower than NPK and 9.3\% lower than control treatment after $4^{\text {th }}$ year crop cycle. The saturated hydraulic conductivity under integrated use of NPK and FYM was $21.4 \%$ higher than sole use of NPK and $95.8 \%$ higher than the control treatment. The increase in the hydraulic conductivity under integrated use of NPK and FYM was mainly attributed to decrease in the bulk density and increase in the effective pore volume.

Irrespective of the treatments, the maximum concentration of water stable aggregates was observed in the 250-1000 $\mathrm{mm}$ size fraction (Fig. 10). The relative distribution of particle size fraction shows that, in general, less than $1 \%$ of soil mass was present in the mineral associated fraction $(<53 \mu \mathrm{m}), 12-14 \%$ in micro-aggregate fraction $(53-250 \mu \mathrm{m})$, $42-53 \%$ in small macro-aggregate fraction, $(250-2000 \mu \mathrm{m})$ and $5-7 \%$ in large macro-aggregate fraction $(>2000 \mu \mathrm{m})$. The percentage of water stable macro-aggregates $(>250$ $\mu \mathrm{m})$ was maximum in NPK + FYM treatment $(73.6 \%)$ followed by control (69.3\%) and NPK (68.1\%) treatment. 
This finding supports the hypothesis that annual addition of manure favoured the formation of macro-aggregates. The concentration of soil organic carbon decreased with the decrease in the size of the aggregates. In general, $<1 \%$ soil organic carbon was present in the mineral associated fraction, $7-12 \%$ was present in microaggregates, $41-53 \%$ was present in macro-aggregates, 5$9 \%$ was present in large aggregates and about $29-47 \%$ of the soil organic carbon could not be accounted in different nutrient management practices (Fig. 11).

From this we can conclude that balanced use of fertilizers and FYM resulted in the significant improvement in the physical properties of Vertisol, i.e. decrease in bulk density, penetration resistance and increase in hydraulic conductivity, soil aggregation and aggregate associated carbon, compared to the sole use of fertilizer NPK and non-use of fertilizer and manure.

Shrestha et al. (2004) investigated the soil organic carbon (SOC) associated with various aggregate size fractions in soil profiles under different land uses. Bulk soil samples were collected from incremental soil depths $(0-10,10$ $20,20-40,40-60,60-80$ and $80-100 \mathrm{~cm}$ ) from sites with the four dominant land use types [forest, grazing land, irrigated rice in level terraces ( $K$ het)and upland maizemillet in sloping terraces (Bari)] of the Mardi watershed (area $144 \mathrm{~km}^{2}$ ), Nepal. The bulk soil was separated into five aggregate size fractions and the associated SOC contents were determined. Soil physical parameters necessary for estimating the soil SOC stock such as bulk density, stone and gravel content, and SOC content, were also measured for each soil depth.

SOC stock in Bari land was higher than in other land use types (Fig. 12). This could be attributed to high inputs of farmyard manure and agricultural residues in the Bari land. The Bari lands are well managed by farmers, in terms of the soil organic matter supply being closer to the farm houses than in K het lands. In the surface soil, grazing land had the highest SOC stock, followed by Bari, forest and $\mathrm{K}$ het, while in depths below $20 \mathrm{~cm}$ Bari lands had the highest SOC stock.

The conversion of forestland into K het land may result in $49 \%$ losses of SOC compared to SOC level in the forest. On an area basis, the SOC losses were $2 \mathrm{~kg} \mathrm{C} \mathrm{m}^{-}$ ${ }^{2}$ by converting forest to $\mathrm{K}$ het. Studies conducted in parts of the tropics and sub-tropics found a 20 to $50 \%$ loss of carbon in the topsoil after forest clearance and conversion to farmland. Internal trading of land uses during the 18-year period from 1978 to1996 indicated net loss of SOC stock by $29 \%$ in the Mardi watershed (Table 3). The results of this study indicate that land use has a significant effect on the SOC content in the soil profile, as well as in the different soil aggregate size-classes. Soils under natural vegetation had a higher SOC content in soil compared to cultivated soil.

\section{Conclusion}

Plants and SOM control soil structure and SOC dynamics. The quantity and quality of residues determine the formation and stabilization of aggregate structure for SOC sequestration. Plant residues through microbial processes generate complex substances that serve as a mechanical framework for linking soil particles into aggregates. Plant roots and residues are the primary organic skeleton to enmesh the inorganic particles together and build macro- and microaggregates while sequestering SOC. There are three major organic binding agents of aggregation: temporary (plant roots, fungal hyphae, and bacterial cells), transient (polysaccharides), and persistent (humic compounds and polymers).

Conversion of natural ecosystems into agricultural lands for intensive cultivation severely depletes SOC pools. A judicious management of soils under competing and diverse land uses is the key to increasing SOM. Use of crop rotations and diverse cropping systems combined with NT practices followed by proper fertilization and irrigation can enhance SOC sequestration.

A relevant mechanism of SOC storage in aggregates is the sequestration of plant debris in the core of soil microaggregates inaccessible to microbial processes. This mechanism is essential to stabilizing aggregates and sequestering SOC. Magnitude of SOC sequestration in the soil system depends on the residence time of SOC in aggregates. Microaggregates are bound to old organic $\mathrm{C}$, whereas macroaggregates contain younger organic material. The SOC confinement in the interior of microaggregates is the source for long-term $\mathrm{C}$ sequestration in terrestrial systems. Ultimately, interactions of clay minerals with C-enriched humic compounds control the protection, residence times, and turnover of SOC within the microaggregates.

Many techniques have been used to assess the SOC distribution in aggregates. Classical methods include SOC determination in aggregate fractions by wet and dry sieving of bulk soil. Isotopic methods including the determination of $13 \mathrm{C}$ and $14 \mathrm{C}$ with mass spectrometry are techniques to quantify the turnover and storage of organic materials in soil aggregates. Other techniques involve the use of computed tomography, X-ray scattering, and X-ray microscopy to examine the internal porosity and inter-aggregate attributes of macro- and microaggregates. The latter approaches may improve our knowledge about the interactions of SOC and aggregate structure, and the location or distribution of SOC within the matrix of aggregates.

Research needs: There are several knowledge gaps in understanding the interactions of soil structure and SOC. Current state-of-knowledge has not unravelled completely the underlying complex processes involved in the sequestration, stability, dynamics, and residence 
times of SOC in macro- and microaggregates. Some key areas which need further research are given below:

There is a need to develop a unique conceptual model of aggregate hierarchy. There is some contradiction among the available models in explaining the aggregate architecture in relation to the SOC dynamics. Classical models state that primary particles form microaggregates and then macroaggregates (Tisdall and Oades, 1982). Contemporary models, in contrast, show that macroaggregates form first and then release microaggregates.

Specific studies assessing the relationship of mechanical properties of aggregates to SOC concentration are few. Current methods to assess SOC distribution in aggregates have not completely unravelled the physical, chemical, and biological mechanisms that control the interactions of soil structure versus SOC distribution. The use of $\mathrm{C}$ isotope techniques has advanced our understanding of aggregate structure and SOC relationships, but comparative studies using more advanced techniques are needed to further examine the SOC dynamics, particularly within macroaggregates at a molecular lebel.

A systematic assessment of the mechanisms of SOC retention in soil aggregates requires a comprehensive and integrated approach of modeling and research experimentation. Modeling could provide insights on the type of soil management practices that can be implemented to enhance $\mathrm{C}$ sequestration under different soil and climate settings. Models that incorporate data on SOC distribution in macro- and microaggregates to predict soil potential for storing atmospheric $\mathrm{C}$ are desirable. Till date there is no model available which can predict the distribution of aggregates and the distribution of soil organic carbon and their quality due to different land use management practices.

\section{REFERENCES}

Adu, J. K. and Oades, J. M. (1978). Physical factors influencing decomposition of organic materials in soil aggregates. Soil Biol. Biochem. 10: 109-115.

Bandyopadhyay, K.K., Misra, A.K., Ghosh, P.K. and Hati, K.M. (2010). Effect of integrated use of farmyard manure and chemical fertilizeres on soil physical properties and productivity of soybean. Soil Till. Res. 110: 115-125.

Baver, L. D. and Gardner, W. H. (1972). Soil physics. Wiley Eastern Limited, New Delhi. pp. 498.

Beare, M. H., Hendrix, P. F. and Coleman, D. C. (1994).Waterstable aggregates and organic matter fractions in conventional- and no-tillage soils. Soil Sci. Soc. Am. J ., 58: 777-786

Blanco-Canqui, H. and Lal, R. (2005). Aggregates: Tensile strength. In: Lal, R. Encyclopidia of Soil Science, Second Ed. CRC press

Boutton, T. W. (1996). Stable carbon isotope ratios of soil organic matter and their use as indicators of vegetation and climate change. Pages 42-82 in T. W. Boutton and Yamasaki, Shin-ichi, eds. Mass spectrometry of soils. Marcel Dekker, Inc., New York, NY

Bronick, C.J. and Lal, R. (2005). Soil structure and management: a review. Geoderma, 124: 3-22.

Buyanovsky, G. A., Aslam, M. and Wagner, G. H. (1994). Carbon turnover in soil physical fractions. Soil Sci. Soc. Am. J., 58: 1167-1173.

Cambardella, C.A. and Elliott, E.T. (1993). Carbon and nitrogen distribution in aggregates from cultivated and native grassland soils. Soil Sci. Soc. Am. J .57:1071-1076.

Crawford, J. W., Matsui, N. and Young, I. M. (1995). The relation between the moisture- release curve and the structure of soil. J. Soil Sci. 46: 369-375.

Edwards, A. P. and Bremner, J. M. (1967). Microaggregates in soils. J. Soil Sci., 18: 65-73.

Emerson, W. W. 1959. The structure of soil crumbs. J . Soil Sci. 5: 235-244.

Gale, W. J. and Cambardella, C. A. (2000). Carbon dynamics of surface residue and root-derived organic matter under simulated no-till. Soil Sci. Soc. Am. J . 64: 190-195.

Golchin, A., Baldock, J. A. and Oades, J. M. (1998). A model linking organic matter decomposition, chemistry, and aggregate dynamics. In: Soil Processes and the Carbon Cycle. pp. 245-266, Lal, R., Kimble, J. M., Follet, R. F., and Stewart B. A., Eds., CRC Press, Boca Raton, FL.

Greene, C. H. and Pershing, A. J. (2007). Climate drives sea change. Science 315, 1084-1085. (doi:10.1126/ science.1136495)

Greenland, D. J. (1965). Interactions between clays and organic compounds in soils. Part II. Adsorption of soil organic compounds and its effect on soil properties. Soils and Fert. 28: 521-527.

IPCC (2007). Climate change impacts, adaptation and vulnerability. Working Group II. Geneva,Switzerland: IPCC.

Jastrow, J.D. (1996). Soil aggregate formation and the accrual of particulate and mineral-associated organic matter. Soil Biol. Biochem., 28: 665-676.

Kasper, M., Buchan, G.D., Mentler, A. and Blum W.E.H. (2009). Influence of soil tillage systems on the aggregate stability and the distribution of $\mathrm{C}$ and $\mathrm{N}$ in different aggregate fractions. Soil Till. Res., 105, 192-199.

Kelly, E. F., Amundson, R. G., Marino, B. D. and DeNiro, M. J. (1991). Stable carbon isotopic composition of carbonate in Holocene grassland soils. Soil Sci. Soc. Am. J ., 55: 16511658.

Kemper, W.D. and Rosenau, R.C. (1986). Aggregate Stability and Size Distribution. In: Klute A, editor. Methods of soil analysis. Part 1. Physical and mineralogical methods. Madison, WI. p 425-42.

Kerr, R. A. (2007). Scientists tell policy makers we're all warming the world. Sci. 315: 754-757.

Lal, R. (2004). Soil carbon sequestration impacts on global climate change and food security. Sci. 304: 1623-1627.

Lal, R., Kimble, J., Follet, R. and Cole, C. (1998). The potential of US cropland to sequester carbon and mitigate the greenhouse effect. Ann Arbor Press, Chelsea, MI.

Mamta Kumari, Chakraborty, D., Gathala, M. K., Pathak, H., Dwivedi, B.S., Tomar, R. K., Garg, R.N., Singh, R. and Ladha, J. K. (2011). Soil aggregation and associated organic 
carbon fractions as affected by tillage in a rice-wheat rotation in North India. SSSAJ 75:560-567.

Mayer, H., Mentler, A., Papakyriacou, M., Rampazzo, N., Marxer, Y. and Blum, W.E.H. (2002). Influence of vibration amplitude on ultrasonic dispersion of soils. Int. Agrophys. 16: 53-60.

Mentler, A., Staudinger, B. and Strauss, P. (2004). Determination of organic carbon (TOC), nitrogen ( $\mathrm{Nt}$ ) and phosphorus (Pt) in Stable soil aggregates fractionated by ultrasound dispersion method. In: From: IPW 4, Proc. 4th International Phosphorus Workshop-Critical Evaluation of Options for Reducing Phosphorus Loss from Agriculture. Wageningen, The Netherlands pp. 62.

Mermut, A. R., Amudson, R. and Cerling, T. E. (2000). The use of stable isotopes in studying carbonates dynamics in soils. Pages 65-85 in R. Lal, J. M. Kimble, H. Eswaran, and B. A. Stewart, eds. Global climate change and pedogenic carbonates. CRC Press LLC.

Oades, J. M. (1984). Soil organic matter and structural stability, mechanisms and implications for management. Plant Soil, 76: 319-337.

Paul, E.A., Paustian, K., Elliott, E.T. and Cole, C.V. (1997). Soil organic matter in temperate agroecosystems: Long-term Experiments in North America CRC Press, Boca Raton.

Perret, J. S., Prasher, S. O. and Kacimov, A. R. (2003). Mass fractal dimension of soil macropores using computed tomography: from the box-counting to the cube-counting algorithm. Eur. J. Soil Sci., 54: 569-579.

Puget, P., Chenu, C. and Balesdent. J. (1995). Total and young organic matter distributions in aggregates of silty cultivated soils. Eur. J. Soil Sci., 46: 449-459.

Rudrappa, L., Purakayastha, T.J., Singh, D. and Bhadraray, S. (2006). Long-term manuring and fertilization effects on soil organic carbon pools in a Typic Haplustept of semi-arid sub-tropical India. Soil Till Res., 88:180-192
Running, S. M. (2006). Is global warming causing more large wildfires? Sci. 313:927-928. (doi:10.1126/science. 1130370)

Sainju, U. M., Terrill, T. H., Gelaye, S. and Singh, B. P. (2003). Soil aggregation and carbon and nitrogen pools under rhizoma peanut and perennial weeds. Soil Sci. Soc. Am. J., 67: 146-155. Schrag, D. P. (2007). Preparing to capture carbon. Sci. 315:812813. (doi:10.1126/science.1137632)

Schutter,M. E. and Dick, R. P. (2002). Microbial community profiles and activities among aggregates of winter fallow and cover-cropped soil. Soil Sci. Soc. Am. J., 66: 142-153.

Shrestha, B.M., Sitaula B.K., Singh, B.R. and Bajracharya, R.M. (2004). Soil organic carbon stocks in soil aggregates under different land use systems in Nepal. Nutr Cycl Agroecosys, 70(2):201-213.

Six, J., Conant, R. T., Paul, E. A. and Paustian, K. (2002). Stabilization mechanisms of soil organic matter: implications for C-saturation of soils. Plant and Soil, 241: 155-176.

Six, J., Elliot, E.T., Paustian, K. and Doran, J.W. (1998). Aggregation and soil organic matter accumulation in cultivated and native grassland soils. Soil Sci. Soc. Am. J., 62:13671377.

Six, J., Elliott, E. T. and Paustian, K. (1999). Aggregate and soil organic matter dynamics under conventional and no-tillage systems. Soil Sci. Soc. Am. J., 63: 1350-1358.

Six, J., Paustian, K. Elliott, E. T. and Combrink, C. (2000). Soil structure and organic matter. I. Distribution of aggregatesize classes and aggregate associated carbon. Soil Sci. Soc. Am. J., 64:681-689.

Tisdall, J. M. and Oades, J. M. (1982). Organic matter and water stable aggregates in soils. J. Soil Sci., 33: 141-163.

Tisdall, J.M. (1996). Formation of soil aggregates and accumulation of soil organic matter. In: Structure and Organic Matter Storage in Agricultural Soils. pp.57-96.

Wild, A. (1988). Russell's soil conditions and plant growth. 11 th ed., JohnWiley \& Sons, Inc. New York. 